University of Rhode Island

DigitalCommons@URI

Open Access Master's Theses

1994

\title{
A Marina Leasing Proposal for the State of Rhode Island
}

William A. Archambault

University of Rhode Island

Follow this and additional works at: https://digitalcommons.uri.edu/theses

\section{Recommended Citation}

Archambault, William A., "A Marina Leasing Proposal for the State of Rhode Island" (1994). Open Access Master's Theses. Paper 1376.

https://digitalcommons.uri.edu/theses/1376

This Thesis is brought to you for free and open access by DigitalCommons@URI. It has been accepted for inclusion in Open Access Master's Theses by an authorized administrator of DigitalCommons@URI. For more information, please contact digitalcommons-group@uri.edu. 
A MARINA LEASING PROPOSAL FOR THE STATE OF RHODE ISLAND BY

WILLIAM A. ARCHAMBAULT

\begin{abstract}
A THESIS SUBMITTED IN PARTIAL FULFILLMENT OF THE REQUIREMENTS FOR THE DEGREE OF

MASTER OF ARTS

IN

MARINE AFFAIRS
\end{abstract}

UNIVERSITY OF RHODE ISLAND

1994 
MASTER OF ARTS

OF

WILLIAM ALFRED ARCHAMBAULT

APPROVED :

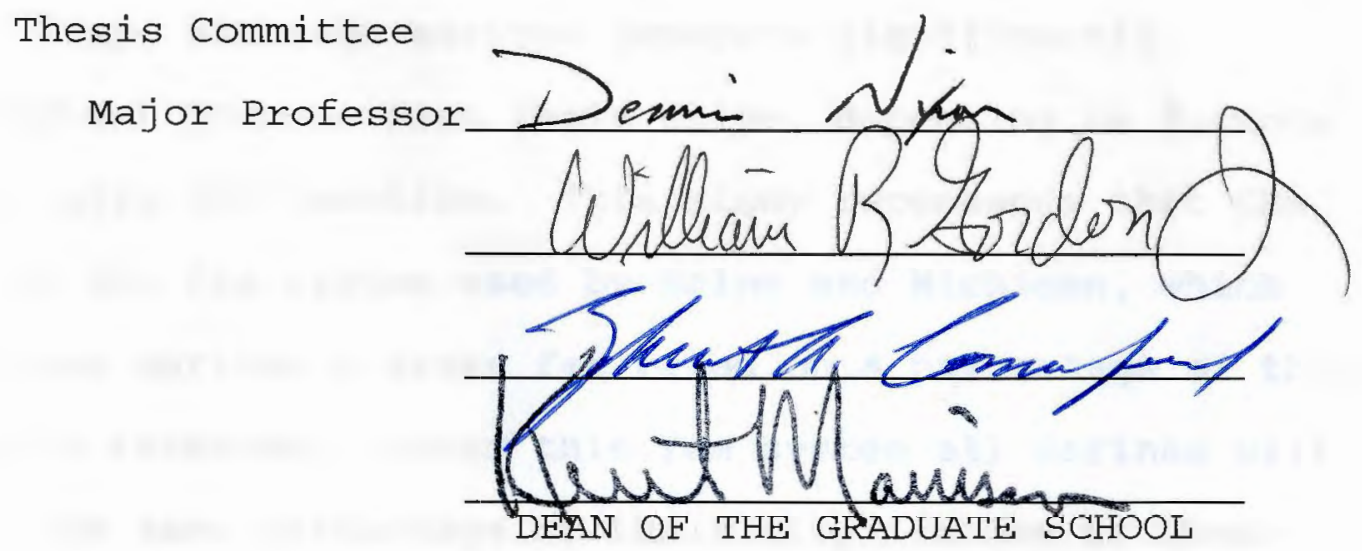

UNIVERISTY OF RHODE ISLAND 


\section{ABSTRACT}

This thesis examines whether Rhode Island has the authority to lease marinas their submerged lands, and if so, is the fee structure of the CRMC's proposed plan equitable to marinas in the state?

The thesis determined that under the powers of the Public Trust Doctrine, Rhode Island has the right to implement a marina leasing program, but implementation of a program may prove to be problematic for the state. The thesis identified that the CRMC's proposed lease rate would be inequitable to marinas in Rhode Island. Marinas subject to the CRMC program would pay the same lease fee per slip, although marinas generate significantly different incomes from their slips, depending on factors like size and location. This study recommends that CRMC adopt the fee system used by Maine and Michigan, which charges marinas a lease fee based on a percentage of their slip's revenues. Under this fee system all marinas will pay the same percentage of their slip incomes to Rhode Island as a lease fee.

As a policy question, this thesis advocates that the CRMC move forward with a marina leasing program in the future. A marina leasing program if implemented properly would benefit both the public and marinas in Rhode Island. 


\section{ACKNOWLEDGEMENTS}

I would like to thank my major professor Dennis Nixon for his continued encouragement throughout my graduate student experience. His support allowed me to complete this thesis and participate as a sea Grant Fellow in Washington D.C.. I would also like to thank Bill Gordon and Bob Comerford for their guidance and agreement to serve on my defense committee. A special thanks goes to my parents and family, for they instilled in me the drive to attain my goals and take pride in achievement of those goals. I must also thank my many friends (too many to mention individually) for their assistance over the last year in helping to complete this project. In particular, I wish to thank my wife Lynn, for without her constant love and support, graduate school and this thesis would not have occurred. 


\section{TABLE OF CONTENTS}

ABSTRACT. ............................

ACKNOWLEDGEMENTS..........................

TABLE OF CONTENTS... $\ldots \ldots \ldots \ldots \ldots \ldots \ldots \ldots \ldots \ldots \ldots$

LIST OF CASES CITED......................

LIST OF TABLES..........................

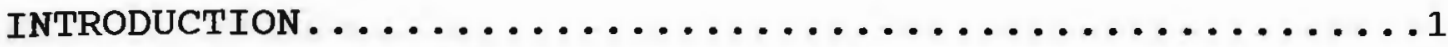

CHAPTER 1 THE PUBLIC TRUST DOCTRINE AND RHODE ISLAND'S

PROPOSED MARINA LEASING PLAN............

CHAPTER 2 LEGAL DECISIONS IMPACTING RHODE ISLAND'S

MARINA LEASING PLAN...............16

CHAPTER 3 A REVIEW OF COASTAL STATE'S

MARINA LEASING PLANS....................

CHAPTER 4 THE RESEARCH HYPOTHESIS.............60

CHAPTER 5 POTENTIAL PROBLEMS IN IMPLEMENTING

RHODE ISLAND'S MARINA LEASING PLAN........82

CHAPTER 6 CONCLUSIONS AND RECOMMENDATIONS.........103

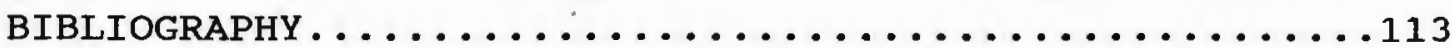


CASES :

PAGE

Boston Waterfront Development Corp. v. Commonwealth,

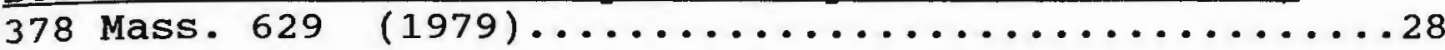

Brusco Towboat $v$. State of oregon,

589, P.2d 712, (OR 1978)..................... 31-44-85

Engs V. Peckham,

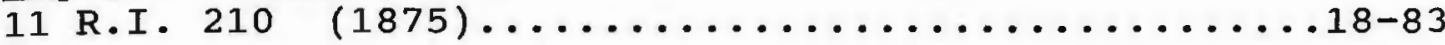

Hall v. Nascimento,

594 A. 2d 874 (R.I. 1991) ...................4-12-16-41

Illinois Central Railroad v. Illinois,

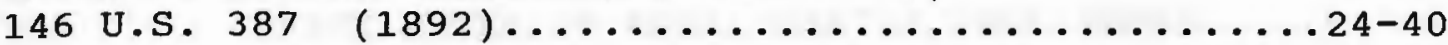

Jackvony v. Powell,

67 R.I. 218, 21 A.2d 554

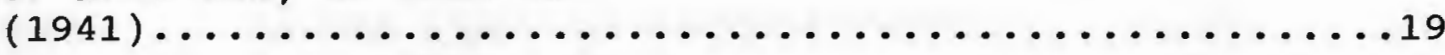

Martin v. Lessee of Waddell,

41 U.S. (16 Peters) 367

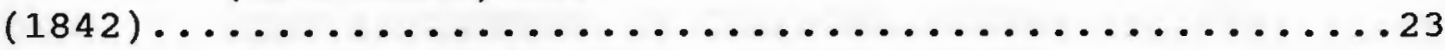

Northeastern Corporation v. Zoning Board of Review,

534 A.2d 603 (R.I.

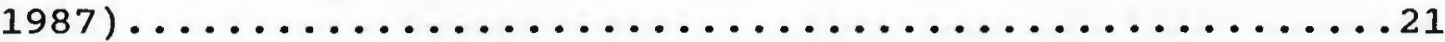

Nugent $v$. Vallone,

161 A.2d 802, (R.I.

$1960)$

Phillips Petroleum Company v. Mississippi,

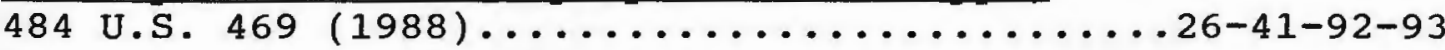

Shively v. Bowlby,

152 U.S. 1 (1894) ........................8-25-34-40

State Land Board v. Sause,

217 OR. 52342 P. 2 d 803

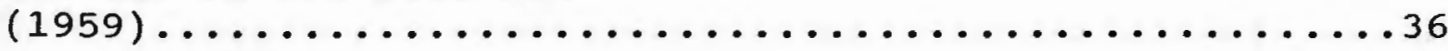

Vermont and City of Burlington v. Central Vermont

Railroad,

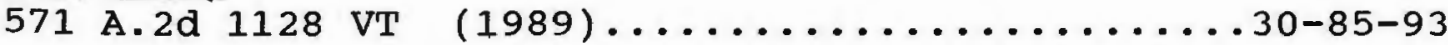




\section{LIST OF TABLES}

PAGE

TABLE 1: MARINA LEASE SYSTEMS IN SELECTED STATES.....63

TABLE 2: SLIP FEES FOR VARIOUS SIZE BOATS..........63

TABLE 3: CURRENT SLIP RATES FOR 30 FOOT BOAT

RHODE ISLAND MARINAS...............68-69

TABLE 4: HOUSEHOLD VALUES AND INCOMES FOR TOWNS

OF THREE SELECTED MARINAS................. 71

TABLE 5: LEASE RATES ON MODEL MARINA FROM THREE

SELECTED STATES AND RHODE ISLAND...........79

TABLE 6: MARINA LEASE OR LICENSE TERMS

IN SELECTED STATES................... 88

TABLE 7: TAX ASSESSMENT OF CARLSONS MARINA

UNDER MAIN'S UPLAND VALUE METHOD...........97 


\section{INTRODUCTION}

For the past 300 years, Rhode Island's shoreline has undergone rapid private development. Submerged lands have been filled and built upon in coastal areas such as Newport and Providence. Developers and land owners have long considered these properties to be private because of registered title. This presumption may be obsolete due to a revival of Public Trust Doctrine concepts. Through its resurgence, Rhode Island state agencies are now planning to use the Doctrine in coastal zone management operations. with the marina industry as one of the most directly affected user groups, a state marina leasing program for submerged lands may be in order.

The implementation of a marina leasing program will be problematic for the state. To enact a program, Rhode Island must challenge the fundamental right of private property ownership. A leasing program for submerged lands would charge fees for lands presently considered as private property by marinas. With much of Rhode Island's shoreline held in private ownership, the public could significantly benefit from a leasing program.

\section{RESEARCH OBJECTIVES AND RELATED HYPOTHESES}

A primary objective of this thesis is to examine and resolve those legal problems associated with establishing a 
marina leasing program. A legal challenge questioning Rhode Island's authority to use the Public Trust Doctrine to implement a lease program is expected. To substantiate that Rhode Island possesses the authority to lease its submerged lands, a review of the Public Trust Doctrine will be necessary. To fully understand the scope of the Doctrine, a review of the Doctrine's evolution in the United States in general, and in Rhode Island in particular, will also be required along with a review of legislation and judicial decisions. Other problems associated with marina leasing, such as insurance liability and bank loans on submerged lands, will also be addressed.

Another goal of this thesis is to provide management information that may be useful to the state of Rhode Island. To accomplish this, a review of other coastal state leasing programs will be conducted. This will identify program elements which could be useful in Rhode Island's management program.

When Rhode Island asserts its ownership over submerged lands by leasing them to marinas, there is a possibility that local tax assessments may be altered. If marinas are expected to pay lease fees, marina owners may request a reduction in their property taxes. This request will come on the basis that the marinas do not own the submerged lands, so they should not be figured in their tax 
evaluations. At this time marinas in Rhode Island are not directly taxed on their submerged lands, but the value of their submerged lands does impact their tax appraisals. If tax assessments are modified a reduction in local property taxes could occur affecting local budgets. This position has already been voiced at public hearings, and legal action on this point is expected. If reductions occur, it is anticipated that Rhode Island's current proposed leasing plan would not compensate towns for reduced tax revenues. To account for tax losses, Rhode Island may have to revise its plan to address this issue.

\section{LITERATURE REQUIREMENTS}

The literature needs are a critical part of this thesis. First, the evolution of the Public Trust Doctrine must be examined. "Putting the Public Trust Doctrine to Work", provides background along with U.S. case history involving the Doctrine (Slade 1990). Literature on the Doctrine's development in Rhode Island is also important. "The Evolution of Public Trust Rights in Rhode Island's Shore", helps one to understand the history of the Doctrine (Nixon 1990). Further information on the history of the Doctrine and its development in the United states judicial system, was attained through various law reviews. The Rhode 
Island Supreme Court decision in Hall v. Nasciemento, 594 A.2d 874 (R.I. 1991), along with the other cases that were reviewed provided insight that was crucial in developing this thesis.

Coastal and landlocked state's leasing programs in the United States were arbitrarily collected and reviewed. From these reviews three lease fee formulas will be selected for further analysis in chapter 4. 
CHAPTER 1 THE PUBLIC TRUST DOCTRINE AND RHODE ISLAND'S PROPOSED MARINA LEASING PLAN

\section{THE ORIGIN OF THE DOCTRINE}

The Public Trust Doctrine is a common law concept that originated during the Roman Empire (Slade 1990). Roman law was derived from the Greeks and developed in a society which relied heavily upon free trade and commerce (Tannenbaum 1985). To promote trade in a time where cargo was primarily transferred by shipping routes, the Romans recognized that certain areas must be kept open to the public. The Institute of Justinian, a principal source of Roman civil law stated:

Things common to mankind by the law of nature, are the air, running water, the sea, and consequently the shores of the sea; no man therefore is prohibited from approaching any part of the seashore, whilst he abstains from damaging farms, monuments, edifices, etc., which are not in common as the sea is. (Tannenbaum 1985).

The public rights of access under Roman law existed in the waters and shores of all bodies of water, and shores that were in fact navigable (Slade 1990). These same principles of public rights in the shoreline remain the foundation for the modern day Public Trust Doctrine.

\section{THE DOCTRINE'S EVOLUTION TO ENGLISH COMMON LAW}

With the fall of the Roman Empire, the evolution of the Doctrine can next be traced to England during the $13^{\text {th }}$ century. At the time of the Doctrine's reappearance, the 
majority of England's coast was held in private ownership (Tannenbaum 1985). This resulted in reduced public access to the shore, hindering commerce as England's economy depended on the sea. These restrictions on public access were one of the factors leading to the Magna Carta signed in 1215, by King John. The Magna Carta was the first charter which guaranteed fundamental rights and privileges under English law (Ibid). After the signing of the Magna Carta the principles of the Public Trust Doctrine appear throughout English Common Law. Although the Magna Carta itself did not specifically create public rights in the shore, it did contain restrictions on the power of the King and nobility to obstruct navigation and claim exclusive control of fisheries.

Although similar to the Roman civil law principles, fundamental changes were made to the Doctrine during its transition to England. Under English common law only tidal waters which were considered navigable contained public trust principles. This limited the public's rights in tidal waters and lands beneath them that were not considered navigable (Slade 1990). Another difference between the Roman and English translations of the Doctrine, was the right of ownership in tidal waters. Under Roman civil law waters and shores were considered incapable of being owned. This concept changed under English common law, which 
assigned to everything capable of occupancy and susceptible of ownership a legal and certain proprietor. The Doctrine now made those things from which their nature cannot be exclusively occupied and enjoyed, the property of the sovereign (Ibid). After the Magna Carta, under English common law all tidal waters and lands beneath them were divided into two distinct types of ownership. The first type of ownership was the public's right of use (jus publicum) held by the sovereign, and embodied by the Parliament. The second type of ownership represents the private rights of possession and exclusive use (jus privatum) presumptively held by the King unless demonstrated that a royal grant had conveyed them to a private proprietor ( Ibid).

In England, the Magna Carta continued to be interpreted broadly to increase the scope of restrictions on the King, to finally become a major source of authority for public rights in England's navigable waters (Tannenbaum 1985). This new interest in establishing public rights in coastal waters and navigable rivers was furthered by $\operatorname{sir}$ Mathew Hale's Treatise, De Jur Maris written in 1670 (Kalo 1990). It was through Hale's treatise that the basis for the English common law rule evolved. The rule changed, so that title to lands over which the tide ebb and flowed were now held by the King, in a sort of trust for the public. The 
importance of this, was that the burden shifted to the private landowner, to prove either that the sovereign had indeed meant to grant to him the tidelands adjacent to his upland property, or that he had acquired a prescriptive right in the land (Slade 1990). With the Public Trust Doctrine now firmly established in England, the sequel of this legal concept can now be traced to Colonial America.

\section{THE PUBLIC TRUST DOCTRINE IN THE UNITED STATES}

As England established the American colonies in the early $17^{\text {th }}$ century, the rules and laws of England were conveyed to the new territories. Along with these laws came the principles of the Public Trust Doctrine found in English common law at the time (Ibid). These principles were established throughout Colonial America's early charters, and continued to be the law of Colonial America following the American Revolution. After the Revolution, English Common Law principles became the foundation for American law. This practice was affirmed 100 years ago in the United States Supreme Court decision of Shively V. Bowlby 152 U.S.

1, 14 (1894). In the decision the court stated:

The common law of England at the time of the emigration of our ancestors, is the law of this country, except so far as it has been modified by the charters, constitutions, statutes or usages of the several Colonies and States, or by the Constitution and laws of the United States. 
Even though English common law provided the foundation for United States law after the Revolution, it was subject to modifications by the states. Despite the application of Public Trust Doctrine principles in all states, no single uniform instrument exists. Instead, the application of the Doctrine varies according to the state, which results in fifty different arrangements connected by the same central theme. It is now pertinent to trace the specific establishment of the Doctrine in Rhode Island, and its particular relevance in Rhode Island's marina leasing program.

\section{THE PUBLIC TRUST DOCTRINE IN RHODE ISLAND}

From its origin as a English Colony to Statehood, Rhode Island has maintained strong ties to the sea. Settled by Roger Williams in 1636 , the Colony was primarily made up of sectarians from Massachusetts and New Plymouth colonies seeking freedoms in religious rights (Nixon 1990). In 1646, King Charles II granted the King charles charter which clearly stated the principles of the Public Trust Doctrine (Ibid). The Charter stated that:

Our Express will and Pleasure is, and we do by these Presents for Us our Heirs and Successors, ordain and Appoint, that these Presents shall not in any manner, hinder any of our Loving Subjects whatsoever from using and Exercising the Trade of Fishing upon the coast of New England in America; But that they, and every, or any of them shall have full and free power and liberty to Continue and Use the Trade of Fishing upon the said 
Coasts in any of the Seas thereunto Adjoining, or any Armes of the Seas, or Salt Water, Rivers and Creeks when they have been accustomed to fish; and to Build and set upon the wastLand belonging to the said colony \& Plantations, such Wharfs Stages and Work-Houses as shall be necessary for the salting, Drying and Keeping of their Fish to be taken or gotten upon the coast.

This Charter established the right of navigation from the coasts to rivers and creeks and is a fundamental principle of the Public Trust Doctrine in Rhode Island (Ibid). The right of navigation found in the charter is based upon public ownership of all navigable waters, and is significant to this thesis.

Public Trust principles can also be found throughout the history of the Rhode Island's Constitution. In a provision adopted in 1842, public rights in the shore are plainly acknowledged (Rubin 1991). Article I, Section 17 of this provision stated that:

The people shall continue to enjoy and freely exercise all the rights of fishing and privileges of the shore, to which they have been heretofore entitled under the charter and usages of the state.

A further amendment to this section in 1970 contained Public Trust Doctrine principles, and affirmed the state's responsibility to protect the public's rights in all the State's natural resources, as follows:

They shall be secure in their rights to the use and enjoyment of the natural resources of the state with due regard for the preservation of their value; and it shall be the duty of the General Assembly to provide for the conservation of the air, land water, plant, animal, mineral and other natural resources of the State, and to adopt all means necessary and proper by law to protect the natural environment of the people of 
the state by providing adequate resource planning for the control and regulation of the state and for the preservation, regeneration and restoration of the natural environment of the state.

Although this amendment mentioned general Public Trust Doctrine concepts, it did not specifically state what the public's rights in the shore are. This issue was resolved by a further amendment in 1986, which clearly affirmed Rhode Island's trust obligation with respect to public rights in the shore. The amendment defined the public's rights as including: (1) fishing from shore, (2) gathering of seaweed, (3) leaving the shore to swim in the sea, (4) passage along the shore, and access to the shore as well as all other rights which had been historically enjoyed (Ibid). This amendment, which was ratified by a large majority of voters in November of 1986, codified public trust common law principles in Rhode Island.

\section{RHODE ISLAND'S CURRENT PROPOSED MARINA LEASING PLAN}

In February of 1992, Rhode Island's Coastal Resource Management Council (CRMC) released a proposed submerged lands leasing program for both private dock owners and marinas (Narragansett Times 1992). The plan would have imposed a lease fee of $\$ 10.00$ on marinas for each slip, and $\$ 100.00$ on private dock owners for each dock. Created in 1971 by the Rhode Island General Assembly, the CRMC was given authority over the State's submerged lands (RI GEN 
LAWS 1979). This includes the responsibility of maintaining Rhode Island's public trust obligations in coastal lands. As state custodian of coastal lands the CRMC has been authorized to charge fees on submerged lands since its creation in 1971. Section 46-23-6 of the Coastal Resource Management Program states "the council may grant licenses, permits and easements for the use of coastal resources, which are held in trust by the state for all its citizens, and impose fees for private use of such resources". Furthermore, section 46-23-16 states "the council is authorized to grant permits, licenses, and easements for any term of years or in perpetuity". In 1978, the CRMC was given additional responsibility when it was established by law as the principal agency to administer and implement Rhode Island's Coastal Resource Management Plan under the Federal Coastal Resource Management Act. It was granted the right to administer the State's plan by Executive order No. 17 which stated:

the state of Rhode Island desires to manage the resources of its coastal region in a manner which achieves the objectives of Section 46-23-1 of the General Laws of 1956 as amended". The Coastal Resource Management Council is established by law as the principal agency to administer and implement the State's Coastal resource management program.

Although the CRMC has held the power to charge fees, it was not until after the 1991 landmark Rhode Island Supreme Court decision in Hall V. Nascimento, 594 A.2d 874 (R.I 1991), 
that the CRMC moved forward with a marina leasing plan. The Hall decision will be discussed in detail in chapter 2 as it is central to this thesis.

In 1992, a legislative task force was created to draft a bill based on the Hall decision and the Public Trust Doctrine. While the task force was working on the legislation, the CRMC issued its proposed marina leasing program. After the CRMC released the program, strong opposition came forth from private shoreland holders and marine groups such as the Rhode Island Marine Trade Association. In March of 1992, the CRMC withdrew from implementing its plan, due to powerful opposition from the user groups, and the economic condition of the boating industry. Marinas in Rhode Island were undergoing economic hardship, and for the first time in many years were having problems filling their slips due to the poor economy. While the marina leasing plan has been put on hold for now, it is expected that the CRMC will try to implement a program in the near future.

\section{RHODE ISLAND MARINA CERTIFICATION PROGRAM}

In January of 1993, the CRMC implemented a marina certification program for all Rhode Island marinas. The program was set up to allow the CRMC and marina owners to absolutely establish, quantify, and document, current in- 
water and upland marina conditions, to permit the marinas as they exist, which will thereby simplify the permitting process (RI Marina Certification 1993). Once established, all routine maintenance and alterations can take place without CRMC consent as long as the design, capacity and purpose or use of the marina is not altered. The application requirements include a description of the marina complex including the existing boat capacity, and a marina perimeter which must be completed by a certified Rhode Island land surveyor. The application also contained a paragraph stating:

the submerged and submersible lands of the tidal, coastal, and navigable waters of the state are owned by the state and held in trust for the public. Conveyance of these lands is illegal; Titles purporting to transfer such lands are void. Assents that involve the filling or use of the states submerged lands are granted with the proviso that it is subject to the imposition of a usage fee to be established by the Coastal Resource management council.

Besides this general statement of Rhode Island's rights, the application has three stipulations that all structures located in the tidal, coastal, or navigable waters of Rhode Island are subject to: (1) The superior property rights of the State of Rhode Island and Providence Plantations in the submerged and submersible lands of the coastal, tidal, and navigable waters; (2) The superior navigation servitude of the United States; (3) The police powers of the state of 
Rhode Island and the United States to regulate structures in the tidal, coastal, or navigable waters (Ibid).

If and when Rhode Island again moves forward with a marina leasing program, it is still anticipated that some marina owners and private dock owners will challenge the state over title to their submerged lands. Although title claims on submerged lands will not generate the controversy that titles to filled tidal lands have, Rhode Island may be forced into court to establish ownership when it moves forward with its marina leasing program. To understand the problems over titles to submerged lands, and other legal problems that may affect Rhode Island's marina leasing plan, a review of past Rhode Island legal decisions followed by a series of pertinent Federal and state court decisions will be examined. 
CHAPTER 2 LEGAL DECISIONS IMPACTING RHODE ISLAND'S MARINA LEASING PLAN

This chapter will focus on legal decisions that may impact Rhode Island's proposed marina leasing program. Through a case review the thesis will attempt to identify that Rhode Island does have the legal authority to implement a marina leasing program. A case review is also needed to highlight certain legal issues left unresolved by the courts. These issues should be identified to allow Rhode Island the time and opportunity to prepare a marina leasing program that covers such problems. Furthermore, the case review will provide Rhode Island with legal precedent by examining other coastal states' case law involving submerged lands.

RHODE ISLAND CASES

\section{HALL V. NASCIMENTO}

A review of Hall V. Nascimento, 594 A.2d 874 (R.I. 1991), is necessary to understand why the CRMC came forward with its proposed leasing program in 1992. The CRMC has maintained the authority to charge lease fees since its creation in 1971, but did not apply the power until after the Hall decision. It also stands as a landmark public 
trust case in Rhode Island, because the land at issue was filled tidal land, not submerged land.

The Hall case involved a dispute over title to a piece of filled land located on Narragansett Bay. The Halls filed suit against Common Fence Point Association after having been denied a bank loan to enlarge their house. The bank refused the Hall's loan after the legitimacy of their property title was questioned. The refusal resulted when their house and septic system were found to be located on a piece of land claimed by Common Fence Point Association. In 1989, the Halls won their case in Superior Court after Judge orton ruled they owned the land through adverse possession. Adverse possession is a method of acquiring title to land where land use is continuous, open and hostile for a time period predescribed by state statute (Kalo 1990).

In July of 1991, the Superior Court decision was overturned in a unanimous decision of the Rhode Island Supreme court. In the decision, Chief Justice Fay found neither the Halls, nor the Association owned the land in question, the state did. Citing the Public Trust Doctrine, Justice Fay stated:

the state maintains title in fee to all soil within its boundaries that lie below the high tide line both filled and submerged, and it holds such lands in trust for the use of the public.

Justice Fay further reinforced Rhode Island's Public Trust rights by declaring: 
such filled or submerged land owned in fee by the state and subject to the public trust doctrine may be conveyed by the state to a private individual by way of a legislative grant, provided the effect of the transfer is not inconsistent with the precepts of the public Trust Doctrine.

of further importance to Rhode Island's proposed marina leasing plan Justice Fay found that:

The defendant's rights, however, are subservient to the state's rights in the property because the state holds title in fee subject to the public trust doctrine.

The Hall decision is significant in that it strengthens Rhode Island's control over submerged lands including filled tidal lands. By finding that the state maintains control even in filled tidal lands, the court has reinforced the State's claim in regards to marinas submerged lands. The decision also gives Rhode Island's CRMC additional authority and responsibilities over filled tidal land, as the agency responsible for managing and regulating coastal properties. With this new authority over submerged lands, it was not long after the decision that the CRMC moved forward with its proposed marina leasing plan.

\section{ENGS v. PECKHAM}

The case of Engs V. Peckham, 11 R.I. 210 (1875), is a leading case in Rhode Island harborline law, which involved a dispute in Newport Harbor in 1875 (Nixon 1990). The dispute began when owners of two adjacent wharves began filling out to Newport's harborline, created in 1873. 
Peckham, by filling out to the harborline's limit was eliminating one half of Engs' wharf capacity. The case becomes important to Rhode Island's proposed marina leasing program because in deciding the case, the supreme court of Rhode Island stated that the establishment of a harborline:

Is equivalent to the legislative declaration that navigation will not be straitened or obstructed by any such filling out. . we hold that establishment of a harborline operates as a license or invitation to the riparian proprietor to fill or wharf out to that line".

The right to wharf out to the harborline is now a well established principle in Rhode Island as stated again in the more recent case of Nugent V. Vallone, 161 A.2d 802 (R.I. 1960). This decision may have created one of the few legal barriers to Rhode Island's marina leasing program. If harborlines are found to be valid legislative grants, then the legislative action of creating a harborline may have transferred the title of submerged lands to wharves and marinas constructed behind them. The problems associated with harborlines and marina leasing will be discussed further in chapter 5 .

JACKVONY V. POWEL

The case of Jackvony V. Powel, 67 R.I. 218, 21 A.2d 554 (1941), involved a challenge by the Rhode Island Attorney General (Jackvony), to an ordinance adopted by the City Council of Newport. This regulation allowed the Newport 
Beach Commission to erect a fence on Easton's Beach which interrupted lateral passage along the shore between meanhigh and mean-low tide lines (Johnson 1988). The case is regarded as a pivotal decision in regards to shoreline rights protected under the Public Trust Doctrine in Rhode Island. Of significance to Rhode Island's proposed marina leasing program, the court restated the principles of the Public Trust Doctrine and then went further by declaring:

"that rights to the shore could not be destroyed even by the legislature".

Through this finding, the Court has fortified Rhode Island's position in claiming some control over its submerged lands. The court found the ordinance unconstitutional, and declared that the phrase "privileges of the shore" has never been clearly defined under Rhode Island precedent.

While the decision establishes that the state maintains some regulatory control over its submerged lands even if claimed by a valid legislative grant, the court did not state, as in the Hall decision that Rhode Island maintains title to its submerged and filled tidal lands. Questions about the extent of a riparian property owner's rights to submerged lands should be expected when the state moves forward with its leasing plan. 
NORTHEASTERN CORPORATION $v$. ZONING BOARD OF REVIEW

The more recent case of Northeastern Corporation $\mathrm{V}$.

zoning Board of Review, 534 A.2d 603 (R.I. 1987), is

important to Rhode Island's proposed leasing plan in that it addresses the question of what are a riparian owner's rights in regards to developing a marina. The case was brought before the court when the developer of a marina-hotel complex did not have the minimum square footage of land to allow his project to proceed (Nixon 1990). The developer claimed that as a riparian property owner, he was entitled to land beneath Trims Pond as part of his overall footage to meet the zoning requirements. In its decision the Rhode Island Supreme court dismissed the claim by finding;

the developer's underwater approach overlooks the well established principle that in this jurisdiction the line of demarcation that separates the property interests of the waterfront owners from the remaining populace of the state is the mean high tide line.

This ruling supports Rhode Island's marina leasing program in two areas. First, it strengthens Rhode Island's position as trustee over submerged lands, by declaring that the mean high tide line divides the property interests between riparian owners and the public of the state. The decision gives Rhode Island the authority of a landowner not just the power to maintain public trust rights in such lands, as was referred to in the Jackvony decision. Second, by giving Rhode Island the power to limit the development rights of a 
riparian owner, the Court has supported the state's right to manage and regulate its submerged lands. This right should also include the authority to lease marinas the state owned submerged lands. 


\section{FEDERAL AND SUPREME COURT CASES}

\section{MARTIN $v$. LESSEE Of WADDELL}

Although established as a principle, the U.S. Supreme and Federal Courts started to address the Public Trust Doctrine early in the $19^{\text {th }}$ century. The first important U.S. Supreme Court decision to address submerged lands was the case of Martin V. Lessee of Waddell, 41 U.S. (16 Peters) 367 (1842). The case arose over a dispute to the title of one hundred acres of submerged land in Perth Amboy, New Jersey, which contained an oyster fishery. In finding that the state retained title, the court declared that:

It will not be presumed that the state intended to part from any portion of the public domain, unless clear and especial words are used to denote it. When the revolution took place the people of each state became themselves sovereign; and in that character hold the absolute right to all their navigable waters and the soils under them for their own common use, subject only to the rights since surrendered by the Constitution to the general government.

By making these statements the U.S. Supreme Court clearly established that submerged land titles were held by the individual States, and is the first of a series of U.S. Supreme Court cases where the court found that the States retained title to their submerged lands. These cases are significant as they provide a strong Federal case precedent to any challenge over title Rhode Island may encounter when it implements a marina leasing program. They also show that 
the Public Trust Doctrine is a valid legal Doctrine that has been confirmed by highest court in the United States since the early $17^{\text {th }}$ century.

\section{ILLINOIS CENTRAL RAILROAD v. ILLINOIS}

The next case that reinforces Rhode Island's right of ownership to submerged lands is the landmark supreme Court Public Trust Doctrine case of Illinois Central Railroad v. IIlinois, 146 U.S. 387 (1892). This case involved a grant by the Illinois legislature to the railroad, granting it the majority of the submerged lands on Chicago's waterfront. The U.S. Supreme Court struck down the 1869 grant by declaring that the state could not relinquish control over property the public had rights in. In the decision the Court declared:

title to public trust land is a title different in character from that which the state holds in lands intended for sale. It is different from the title the United States holds in the public lands which are open to preemption and sale. It is a title held in trust for the people of the state that they may enjoy the navigation of the waters, carry on commerce over them, and have liberty of fishing therein freed from the obstruction or interference of private parties.

The court went even further in establishing individual state rights by stating:

a conveyance of public trust land into private ownership solely to further private interests violates the Public Trust Doctrine and a state can convey trust land only if the land can be disposed of without any substantial impairment of the public interest in the lands and waters remaining. 
This decision again established the individual states as a property owner in such lands, rather than assigning regulatory authority through their sovereign police powers (Slade 1990). That control is important for Rhode Island, because leasing land requires ownership authority rather than regulatory authority. Illinois Central still stands as the most significant Public Trust case in U.S. history, and is cited repeatedly in cases involving title to submerged lands. The Court's decision confirms that any challenge by Rhode Island marinas in claiming their submerged lands, would most likely be denied without a valid legislative grant. Furthermore, even with a valid legislative grant, the state still maintains some regulatory control.

\section{SHIVELY V. BOWLBY}

Soon after the Illinois Central Railroad case, the Supreme Court again examined the principles of the Public Trust Doctrine in the case of Shively V. Bowlby, 152 U.S. 1 (1894). In Shively, the issue was whether oregon or a prestatehood grantee from the U.S. of submerged lands on the Columbia river, held title to the lands below the high water mark. After reviewing prior Court cases, English common law, and various cases from the state courts, the court found:

At common law, the title and dominion in lands flowed by the tide water were in the king for the benefit of 
the nation. Upon the American Revolution, these rights, charged with a like trust, were vested in the original states within their respective borders , subject to the rights surrended by the constitution of the United states.

The decision affirmed that following the Revolution, Public Trust rights were transferred to individual states. This case is still recognized as the seminal case in American public Trust jurisprudence, and its principles are still being upheld, as the next case will demonstrate. For Rhode Island's marina leasing program, this is another case that validates the State's rights to its submerged lands. Also, as one of the original states, the Court's statement that "public trust rights were transferred from the King to the original States", would apply directly to Rhode Island.

\section{PHILLIPS PETROLEUM COMPANY v. MISSISSIPPI}

The last U.S. Supreme court case to be reviewed is Phillips Petroleum Company V. Mississippi, 484 U.S. 469 (1988). This recent Supreme Court case involved a Public Trust issue, much like shively. The issue was whether the State of Mississippi, when it entered the Union in 1817, took title to lands lying under waters that were influenced by the tide running in the Gulf of Mexico, but were not navigable in fact.

Citing Shively the court found:

Because we believe that our cases firmly establish that the States, upon entering the Union, were given ownership over all lands beneath waters subject to the 
tide's influence we affirm the Mississippi supreme court's determination that the lands at issue here became property of the state upon its admission to the Union in 1817 .

Furthermore and relevant to Rhode Island's proposed marina leasing program is the court's statement:

the fact that petitioners have long been the record title holders, or paid taxes on these lands does not change the outcome.

The Phillips decision gives Rhode Island a secure claim over its submerged lands. Even if marinas claim their deeds define the title to their submerged lands, the U.S. Supreme court decision in Phillips has determined the outcome of such a challenge before a Rhode Island court. The decision along with the additional U.S. Supreme court cases previously discussed, leaves Rhode Island marinas with few valid claims to their submerged lands. One possible instance would be where a legislative grant from the Rhode Island General Assembly, granted a riparian owner his submerged lands.

In Phillips the U.S. Supreme court also addressed the issue of whether paying taxes on submerged lands establishes title to the lands. This issue may be raised in Rhode Island, but the U.S. Supreme court decision in Phillips should discourage marinas from such a claim. 
RELEVANT DECISIONS FROM OTHER STATE JURISDICTIONS

In order to illustrate the connection between the Public Trust Doctrine and marina leasing it is also necessary to examine other cases from state courts that involve submerged lands. The first two cases involve title claims on filled lands. Although the Rhode Island marina leasing plan involves only submerged lands, these cases are important for Rhode Island because they resolved issues that may become problematic for the state when leasing its lands. They also reinforce the power and scope of the Public Trust Doctrine in regards to submerged lands. The third case to be reviewed is one in which the fundamental reason for this thesis is involved: Whether a state has the right to charge lease fees on its submerged lands.

BOSTON WATERFRONT DEVELOPMENT CORPORATION v. COMMONWEALTH In Boston Waterfront Development Corp. v. Commonwealth 378 Mass. 629 (1979), the issue involved a dispute over title to a small piece of filled land at the end of a wharf extending into Boston Harbor. The Boston Waterfront Development Corporation claimed fee simple absolute to land, which was filled pursuant to wharfing statutes in the $1800 \mathrm{~s}$ (Rubin 1990). In its decision, the Massachusetts Supreme 
court found that the wharf statutes were valid legislative grants, by stating that:

the land below low waterline can be granted by the state only to fulfill a public purpose, and the rights of the grantee to that land are ended when that purpose is extinguished.

The reason the court defined the boundary as the low water mark, is that in Massachusetts and Maine the jurisdiction over submerged lands begins at the mean low water mark rather than mean high water mark (Slade 1990). This decision may be used by Rhode Island Courts to determine whether harborline acts are similar to the Massachusetts wharfing statutes. If Rhode Island Courts find that harborlines are valid legislative grants, then the state may not have the right to lease marinas the submerged lands which fall behind such harborlines.

This case is also important to Rhode Island in that even if a valid legislative grant did exist on marinas' submerged lands, that grant must be for a public purpose and the state maintains that interest in perpetuity. This finding is similar to the U.S. Supreme Court's decision in Illinois Central Railroad. Marinas that are open to the public would most likely be found to provide such a public purpose as defined by the court. The problems arise with yacht clubs and private marinas, as they exclude the public. Although Rhode Island may not have the authority to charge lease fees on marinas with submerged lands granted to them 
through the legislature, it may have the power to require some type of payment for such private use of a public resource. The state could require some type of public access as payment, such as public use of transit slips or boat ramps.

STATE OF VERMONT AND CITY OF BURLINGTON V. CENTRAL VERMONT RAILWAY .

The case of state of Vermont and City of Burlington v. Central Vermont Railway, 571 A.2d 1128 (Vt. 1989), involves an issue somewhat like that of the Boston Waterfront case. In this case, Vermont brought action against the railroad after the railroad sought to sell into private ownership filled lands on Lake Champlain. In 1827, legislation was enacted that granted littoral owners on Lake Champlain the right to erect wharves by filling submerged lands. The purpose of the Act was to increase commerce without spending public funds. From 1849 to 1972 , the railroad company continually filled in an area along the lake to bring the railroad to the lake. Citing Illinois Central and Boston Waterfront the court found:

that the legislature did not intend to grant the lands at issue free of the public trust, and concluded that Central Vermont Railroad does not hold title to the filled lands free of public trust.

The court also addressed the issue of whether occupying a piece of property and paying property taxes on it 
established ownership in the property. In this case, Central Vermont Railroad maintained that under the Doctrine of Laches, the City and state should be barred from any claims on the property. The Doctrine of Laches provides a party with an equitable defense where long neglected rights are sought to be enforced against the party (Gifis 1984). The Doctrine also concedes that if the delay has led the adverse party to change his or her position as to the property or right in question, it is inequitable to allow the negligent delaying party to be preferred in their legal right. Addressing the Doctrine of Laches the Court stated:

we hold that the claims asserted here cannot be barred through either Laches or Estoppel. As the Supreme Court of California has observed, the state acts as administrator of the public trust and has a continuing power that extends to the revocation of previously granted rights or to the enforcement of the trust against lands long thought free of the trust.

This decision regarding property taxes along with the decision in Phillips Petroleum supports Rhode Island if challenged over whether paying property taxes establishes a property right.

BRUSCO TOWBOAT $v$. STATE OF OREGON

The last case to be examined, and of particular importance to this thesis is Brusco Towboat $v$. State of Oregon, 589, P.2d 712, (Or. 1978). This case involved a challenge to Oregon's Land Boards requirement that permanent 
structures on or over state owned submerged and submersible lands under navigable waters enter into a lease and pay rent. A challenge on similar grounds, disputing the Rhode Island Coastal Resource Management Council's (CRMC) authority, may occur when Rhode Island finally moves forward with its marina leasing plan. In Brusco the court considered the following four issues, which may be similar to problems encountered when Rhode Island moves forward with its marina leasing plan.:

1) Whether the State has the power to lease marinas their submerged lands, and whether the authority to do so has been given to the State Land Board.

2) Whether the Board, if it has the authority to impose a leasing program, has calculated its rental fees on an improper basis.

3) Whether the leasing program impairs, or is constitutionally limited by, the rights of riparian owners. 4) Whether the State may charge lease fees on structures existing prior to the establishment of a leasing program. Addressing the first question of whether the state has the power to lease its submerged lands the court concluded: we find no provision in the state Constitution which denies to the legislature (or the Board) the power to require occupiers of state-owned submerged and submersible lands to enter into leases and compensate the state for their use.

It then went further and declared: 
the state legislature has specifically authorized the Division of State Lands to lease state-owned submerged and submersible land.

The decision established that oregon has ownership over its submerged lands and the right to lease them. Furthermore, it established that the state has legislative authority to create an agency to lease and manage its submerged lands. The next issue addressed is if the Board does have the authority to impose the leasing program, is it calculating its rental fees on an improper basis. The issue is important for Rhode Island not because it questions a type of leasing fee formula, but because it questions the actual area of submerged land on which the state has the right to charge fees. The plaintiffs claimed oregon erred when it based its calculations on the total amount of water surface area which is occupied, rather than the amount of bed area occupied by pilings, dolphins, or other structural features which actually touched the bed. Brusco Towboat claimed this was wrong because the public, not the state in its proprietary capacity, is the owner of the State's waters. In its decision the court stated:

We need not reach that question. The State's ownership of the submerged and submersible lands alone is sufficient to justify the rental which the Board proposes to charge for occupation of the surface of the water.

Although this statement reinforces state's rights to lease their submerged lands, the court also addressed the question 
of area in which Oregon has the right to lease when it found:

we are aware of no general principle which requires a lessor, whether public or private, to calculate rentals on any particular basis such as the amount of surface area physically in contact with structures.

Although the question of area in which the state may lease has not been raised at public hearings in Rhode Island, it may be an issue that is brought up in the future. If this issue is brought before a Rhode Island Court, the outcome will most likely be similar to Brusco.

The next question Brusco addresses, which may be of significance to Rhode Island, is whether riparian owners have a right, which may not be taken without compensation, to place permanent structures on the state's submerged and submersible land adjacent to their riparian property. This question poses a potential barrier for states in leasing lands to riparian owners. If a Rhode Island court found that a property right did exist for owners to build on their submerged lands, then the state may have to compensate riparian land owners for the property rights they would lose under a marina leasing plan. Under the Fifth Amendment of the United States Constitution " No person shall be deprived of life, liberty or property, without due process of law; nor shall private property be taken for public use, without just compensation". In finding for oregon the court quoted Shively V. Bowlby, 152 U.S. 1 (1894), when it stated: 
an upland owner on tidal waters has no rights as against the state or its grantees to extend wharves in front of his land, or to any private or exclusive rights whatever in the tide lands, except as he has derived them from the statute.

The court went on to cite further cases supporting that riparian owners hold no property rights and stated:

we find, then, no authority for plaintiffs' position that riparian owners on navigable waters have a right to build navigational structures on state-owned beds adjacent to their property which may not be revoked without compensation prior to its exercise.

The Court's decision allowed Oregon to charge lease fees on all submerged lands, whether occupied before or after the creation of the leasing program. It is expected that Rhode Island Courts would decide such a case in a similar manner, and allow the CRMC to implement its leasing program on all existing marinas. Furthermore, the marinas claim that occupation of their submerged lands creates a property right which can not be taken away, should not hold up in a Rhode Island Court. Rhode Island has laws that prevent adverse possession of public property, and possession of a property right should fall under the same statute. The oregon court did acknowledge that in a series of New York cases, some appear to hold that riparian owners do have such a right. As the law of property is state law it will be up to Rhode Island's Courts to decide this issue. 
The last question Brusco addresses, is whether oregon may charge lease fees on structures existing prior to the leasing program. This issue would concern Rhode Island, as its leasing program would primarily be charging lease fees on marinas that were in existence before the creation of the CRMC. If limited to charging lease fees on marinas developed after the CRMC was created, Rhode Island's leasing program would be restricted to the few marinas developed after 1971. That was the year the CRMC was created and authorized to charge fees for the use of submerged lands. After citing the case of state Land Board V. Sause, 217 or. 52342 P. 2 d 803 (1959), which involved title to a narrow strip of tideland, the court stated:

it is clear from the quoted portion of the opinion that we did not regard the riparian owner's occupation of adjacent state-owned tidelands as creating a vested property right which could not thereafter be taken by the state without compensation.

The Towboat company claimed that the legislature's past failure to prohibit their exclusive occupation of the State's submerged lands constituted a passive or implied license, and under that license they could continue to occupy the lands free of rent. The Oregon supreme Court of Appeals found for Brusco when it claimed the rule of licenses applied to Brusco Towboat's submerged lands. The rule generally applies where capital and labor have been spent, the granting of a license is made in reasonable 
reliance upon representations by the licensor as to the duration of the license. Therefore, Brusco Towboat is privileged to continue the use permitted by the license to the extent reasonably necessary to regain their expenses. The Oregon Supreme Court overturned the decision finding that the rule did not apply to Brusco. In deciding this issue the oregon Supreme Court found:

Between private parties, the general rule is that when expenditures have been made to construct permanent improvements on anothers land in reliance to an expressed license to do so, the license cannot thereafter be revoked, at least without payment of compensation. This rule is, however limited to expenditures made in reliance to an expressed license or agreement, and does not apply where the landowner has not given expressed permission, but has merely silently acquiesced or failed to object to the improvements.

This decision gave oregon the flexibility to lease its submerged lands. If a similar claim is brought before a Rhode Island Court, the state should maintain that any marina development that took place before CRMC's creation was done under a passive or implied license. To prove the existence of an expressed license, a marina would need to demonstrate a link with Rhode Island in the past. This will be difficult in Rhode Island, given that no state regulatory agency existed for marinas prior to 1971. Until CRMC was created in 1971, a marina could be constructed without obtaining permits or permission from the state. The only situation where a marina may claim it was developed under an 
expressed license or agreement with the state, would be where a marina existed behind a harborline created by the legislature. 
CHAPTER 3 A REVIEW OF COASTAL STATES MARINA LEASING PLANS

In this chapter positive and negative points of current and proposed marina leasing plans from various coastal states will be reviewed. These plans were selected from the coastal states that maintain marina leasing programs, and are assumed to be representative of the types of leasing programs found throughout the United States. To obtain these plans, states were contacted by phone or mail to inquire if they administered a marina leasing program. From this contact, twenty states submitted some form of submerged lands program pertaining to a marina's submerged lands. These programs ranged from states with well established marina leasing programs, to states where recent legislation has enabled them to begin to establish a marina leasing program.

To collect information a comparison case study of the state's marina leasing plans will be conducted. The basis for these comparisons is to emphasize the program elements of other states' marina leasing programs, that may be useful to Rhode Island. The first element of the programs to be compared will be the history and origin of each plan. This review will provide Rhode Island with information on what preceded the creation of other states' marina leasing plans. It is expected that this will demonstrate that Rhode 
Island's current situation is not unique. Next, the structure and type of lease fee formula used by each state will be identified. The lease fee formulas most tepresentative of programs in general will then be selected for calculations conducted on a model marina in chapter 4. The standards connected to each states' lease in regards to lease terms, liability, and tax provisions were also highlighted for comparisons. That information was required for the discussion of problems associated with marina leasing in chapter 5 .

While most state plans were different in some aspects, the Public Trust Doctrine was the one common theme in all programs. The Doctrine remained the basis and foundation for every submerged land leasing program in the United States. In many states such as California, oregon, and Mississippi, the leasing programs start out with a brief history of the Public Trust Doctrine, including references to such landmark U.S. cases as Illinois Central Railroad V. Illinois, 146 U.S. 387 (1892), and Shivley V. Bowlby, 152 U.S. 1 (1894). Now well established in American Common Law, the Public Trust Doctrine will remain the principle behind submerged land leasing programs. 


\section{MISSISSIPPI'S MARINA LEASING PROGRAM}

The history behind Mississippi's marina leasing program is very similar to Rhode Island's. Although Mississippi held responsibilities as trustee of submerged lands, it took the U.S. Supreme Court case of Phillips Petroleum Company V. Mississippi, 484 U.S. 469 (1988), to get Mississippi to develop a submerged lands leasing plan (Jarman 1990). This is similar to Rhode Island's situation where the R.I. Supreme Court decision in Hall V. Nascimento, 594 A.2d 874 (R.I. 1991), gave the Rhode Island CRMC the incentive to develop a marina leasing program.

In response to the Phillips decision in June of 1988, the Mississippi Secretary of State established a Blue Ribbon Commission on Public Trust tidelands to produce a sound and equitable tidelands leasing program for the State (Nelson 1990). The Commission contained 26 members from different occupations, but was primarily composed of elected officials and lawyers. A review of the Commission's membership reveals the following makeup: five lawyers, seven elected officials, five business persons, one ex-state official, one hospital administrator, two college administrators, one environmental organization representative, and one minister (Ibid). The commission was broken into five committees addressing boundaries, littoral/riparian rights, conservation and development, taxation, and lease program 
management (Mississippi Blue Ribbon Report 1989). The commission met eight times in 1988, and all meetings were open to the public, including time for public comment. The commission drafted its final report in December of 1988, and the recommendations including the marina leasing recommendations were then adopted without change into administrative rules. At the same time, the secretary sought comprehensive legislation that would duplicate the commission's recommendations. The secretary wanted a clear legislative mandate, because as trustee of submerged lands, he held the authority to implement some, but not all of the Commission's recommendations (Ibid). Under strong protest from coastal businesses and landowners, two Bills were introduced in the House of Representatives and Senate to create a submerged lands leasing program. On March 31, 1989 a compromise bill which contained most of the Commission's original marina leasing recommendations was signed into law. From the Commission's recommendations and public input, Mississippi now has a well organized marina leasing program. Some of the important features of the program include the following conditions: 1) all revenues from marina leases go to the Bureau of Marine Resources for programs on tideland management; 2) the rules require that once trust lands are leased, the lessee is responsible for any county or municipal taxes levied upon the leasehold (Mississippi 
Submerged Land Rules 1991); 3) the lessee maintains a policy of liability insurance, and to indemnify and hold harmless the lessor from and against all claims for damages or injuries no matter how caused. The maximum term granted for a marina lease is 40 years, with an automatic option to renew for an additional 25 years. The lease fee for marinas was established at $\$ .07$ per square foot, with rent adjustments taking place every 5 years based on the consumer price index or an appraisal, whichever is greater. Finally, to maintain some public access in all marinas, marina operators must make available at least $10 \%$ of authorized slips to the general public on a first come, first serve basis at a reasonable fee.

\section{OREGON'S MARINA LEASING PROGRAM}

In Oregon, the framework for a marina leasing program began in 1963, when the Oregon legislature enacted oRS 274.915. This statute authorized the Division of State Lands to lease oregon's submersible and submerged lands. Oregon voters further strengthened the State's authority in 1968, by enacting Article 8-5(2) to the state Constitution, which authorized the state Land Board to manage State lands with the object of obtaining the greatest benefit for the people of the state. Although Oregon empowered the Land Board to implement a marina leasing program in 1963, it was 
not until 1977, that the state issued rules establishing a program for leasing state-owned submerged lands. Unlike Mississippi where a Court decision led to a leasing program, in oregon it was the issuance of these rules that initiated a lawsuit Brusco Towboat v. State of oregon, 589, P.2d 712, (or. 1978). After the state prevailed in Brusco, oregon had both judicial and legislative authority for its marina leasing program.

The following procedures are now part of Oregon's marina leasing rules issued by the state Land Board, including updates approved in January of 1992. All fees from submerged lands are deposited in the Common School Fund for distribution to public school districts around the state (Oregon Administrative Rules 141 82. 005-035 1992). This fund currently generates $\$ 850,000$ in income per year from 500 submerged land leases including marina leases (Hedrick 1992). The new rules require marinas to have proof of insurance, indicating the state of oregon as additionally insured. Terms for marina leases are usually for 20 years, but in some cases, where there are lender problems, the State will allow for longer terms up to 40 years. To address marinas that may have experienced lender problems, Oregon now allows marinas to lease the lands for the term of any existing mortgage plus 10 years, as long as the term does not exceed 40 years. Oregon has one of the lowest fee 
rates in the United States, with fees being calculated per acre of submerged land, at a rate of $\$ 418.00$ for the first acre, and $\$ 251.00$ for any additional acres. When this rate is broken down into cost per square foot, the rate comes out to less than $\$ .01$ per square foot. To assist in calculating the fee, Oregon has established a procedure that requires marinas to square off their submerged lands into rectangular areas.

oregon does maintain one unusual feature in its marina leasing program called the hardship rate (Oregon Administrative Rules $14182.005-035$ 1992) . This rate allows marinas to defer their lease fees for up to two years. To qualify for a hardship deferral, a marina must have undergone an extraordinary and unforeseeable occurrence or act of God, and the event must have taken place more than 90 days prior to the date the request was submitted. Examples of where the hardship rule would apply are a fire at the marina or damage caused by an earthquake or tsunami. In Rhode Island this rule could be used when marinas suffer damage during hurricane season, or winter ice damage exceeding a certain dollar amount.

\section{CALIFORNIA'S MARINA LEASING PROGRAM}

With over 1,100 miles of shoreline and 4 million acres of submerged lands, California has one of the largest marina 
leasing programs in the United States. Submerged lands in California are managed by the State Lands Commission, which was established by the legislature in 1938 (California Land commission 1990). While California's marina leasing program does not have a history of judicial decisions behind it, it does stand out from other programs on its discretion and flexibility. Article 2 (b) of the California Code of Regulations reads:

Leases or permits may be issued to qualified applicants and the Commission shall have broad discretion in all aspects of leasing including category of lease or permit and which use, method or amount of rental is most appropriate, whether competitive bidding should be used in awarding a lease, what term should apply, how rental should be adjusted during the term, whether bonding and insurance should be required and in what amounts, whether an applicant is "qualified" etc. based on what it deems to be in the interest of the state.

With regards to lease fees, California's regulations represent a unique example, since each lease fee is negotiated on a case by case basis. With no established lease rate, fees are based on one of two methods. 1) a percentage of annual gross income, or 2) $9 \%$ of the appraised value of the leased land (California Article 2 1990). The gross income percentages can range from $5-12 \%$ and are reevaluated every 5 years, making California's rates one of the highest in the United States. Fees generated from marina leases are put into a general fund for distribution to various state programs ranging from education to water 
resources. Lease terms are also negotiable and average around 25 years, with a maximum term of 49 years permitted when financing requires it (Ibid). Applications for renewals are treated like new applications and dealt with on a case by case basis.

Another area that makes California's marina leases unique, is the stringent environmental regulations connected to each lease. All marinas whether proposed or existing, must include detailed environmental information with the lease application. This information includes identification of the type and location of any known habitat of rare, threatened, or endangered species of plant or animal within a one mile radius of the site, and the type and location of any vegetation at the site. A description of all pollution control measures for vessel maintenance and haulout facilities must be included, along with methods used to control runoff and waste removal (Ibid). Copies of the all original or new environmental documents, including California's required Environmental Impact Report (EIR), must be submitted before a lease will be reviewed. In addition to these documents, a $\$ 10,000.00$ minimum expense fee must be included to pay for the commission's cost to process the lease permit. With such requirements, it is not unusual for a marina to consult with professional help when seeking a lease. 


\section{MAINE'S MARINA LEASING PROGRAM}

Maine began a marina leasing program after its submerged Lands Act was passed and adopted in October of 1975 (Maine 12 M.R.S.A 558 1975). The Act gave the Bureau of Public Lands (BPL) of the Department of Conservation the authority to lease interests in submerged lands. To avoid confrontation and allow existing submerged land users time to adjust, Maine imposed limitations on its own jurisdiction. The Act granted certain marinas a thirty year constructive easement on obtaining a lease. Under the Act, all marinas existing prior to october 1, 1975 were given permission to operate until September 30,2005 without entering into a lease agreement or pay rent. An easement is a right, created by an express or implied agreement, of one owner of land to make lawful and beneficial use of the land of another (Gifis 1975). The easement is valid, only for the particular use in existence, and any significant changes in the nature, intensity, or location of the use would require a new lease or easement (Maine Sea Grant 1991). Due to this grant, only 29 of the 80 existing marinas in Maine pay lease fees as of 1991 (Zarafonitis 1991). These 29 marinas have claimed that they are being subjected to an economic disadvantage (Oliveri 1992). Marinas that qualified for an exemption still must pay a $\$ 50.00$ fee for 
the easement, and a $\$ 25.00$ registration fee every 5 years (Maine 12 M.R.S.A. 558 1975). To initiate full

mplementation of the program all marinas must be registered by 1995 , ten years before the exemptions run out, or face a fine (Oliveri 1992).

Another limitation became effective in 1981, when Maine granted to upland owners all interest in lands which were historically submerged or intertidal lands, but which had been filled prior to October 1, 1975 with or without governmental permission (Maine sea Grant 1991). These lands became private lands, free of any public easement or public trust restrictions.

Lease fees in Maine have evolved over the years to the current rate of $4 \%$ of the marina slip gross income. When the Submerged Lands Act was passed in 1975, all submerged lands fees, regardless of use, were set at $\$ .01$ per square foot per year. Over the next nine years the fee climbed to $\$ .03$ per square foot, after which the formula was amended in 1984, to distinguish between water dependent and nonwater dependent uses (Ibid). Following the 1984 amendments, marinas' fees were reduced to $\$ .02$ per square foot, where they remained until 1988. In 1988, in response to issues involving dockominiums, Maine established a committee to study several issues including its fee system. In response to the Committee's recommendations the Legislature enacted 
amendments to the fee system effective April 1990. Under the new system, called the upland value method, marina lease fees were to be based on the assessed value of an equal amount of adjacent uplands. To calculate the values, the tax assessments were taken from the towns in which the marinas were located. From the assessed value the fees were then adjusted to reflect the submerged lands use, with recreational marinas paying $2 \%$ of the municipally assessed value of the adjacent upland. This fee system which is discussed in Chapter 4, charged each marina a different fee, depending on the tax rate of the town in which the marina was located. In April 1991, after many marinas challenged the method, Maine once again amended its fee system to its current percentage of slip revenue method (Maine Sea Grant 1991).

The balance of Maine's leasing program has remained the same since the Act's passage in 1975. After the program's administrative costs are covered, all revenues go to a dedicated fund set up for harbor management projects (Maine 12 M.R.S.A. 558 1991). The maximum lease term allowed is 30 years to coincide with the granted easements, and renewals are subject to public access conditions required under the Public Trust Doctrine. Maine may also cancel a lease if marinas violate the public access requirements of their current lease (Ibid). 
FLORIDA'S MARINA LEASING PROGRAM

Florida's marina leasing program is administered by the Bureau of Submerged Lands and Preserves, within the Division of State Lands, located in the Florida Department of Natural Resources (Miller 1992). The Bureau has management responsibilities for over 7.6 million acres of submerged lands, that are used for a variety of functions, such as offshore oil drilling, commercial marinas, aquaculture, etc. (Ibid). The Bureau implemented a statewide marina leasing program on March 3, 1982 when it issued Chapters 18-20, and 18-21 of the Florida Administrative Code, titled "Rules for Management of Sovereign Submerged lands" (Florida Administrative Code 18-21 1982).

Before the establishment of a marina leasing program, Florida had issued marinas a license which was renewed annually. Since Florida established a marina leasing program, it has taken significant steps to get all marinas registered in the program. These steps include grandfather provisions for marinas that initially qualified for an exemption, and amnesty for marinas that originally failed to register. Like Maine, when Florida began its marina leasing program it offered lease exemptions for marinas operating before a certain date. To qualify for a grandfather exemption a marina had to prove its existence prior to March 
10, 1970 (Ibid). To establish its existence a marina must provide an aerial photo of the marina dated prior to March 10, 1970 or evidence of prior authorization by a Florida agency. Marinas seeking the grandfather provision were given a two year deadline in which to apply for the exemption. The marinas that qualified under the grandfather provisions are now exempt from a lease until January 1, 1998. After January 1, 1998 all marinas must be under a lease or face fines and penalties. Seeking to bring more marinas into the leasing program in December of 1990, Florida offered marinas an amnesty program. The amnesty program applied to all marinas not currently under a lease, including marinas that initially qualified for the grandfather exemption, but did not apply. The marinas were excused from all penalties and back fees, as long as they were brought under a lease by April 1, 1991. Marinas that were originally eligible for exemptions under the grandfather provision were now only eligible for amnesty to 1991 (Ibid). To provide marinas with advance notice of the amnesty program, a letter was sent out to condominium associations and the program was widely advertised in newspapers around the state (Flannery 1990).

Other aspects of interest in Florida's marina leasing program include its fee system and lease term. Florida has a two tier lease fee formula, in which there is a standard 
fee and a base fee. The standard annual lease fee is $7 \%$ of the rental value from the wet slip rental area (Florida Rules 18-21.011 1982). The fee is calculated by multiplying the total number of linear feet for rent in the wet slip rental area times the weighted, average, monthly per linear foot rental rate, multiplied by twelve. At this time many marinas in Florida are still under the base fee system. The base fee is calculated at $\$ .085$ per square foot of submerged land, and is computed annually. For new marinas, the base rent is charged upon approval of the lease, after which the standard rate is applied when the facility is certified complete by the lessee, or when any rentals occur, whichever comes first (Ibid). To promote public access Florida offers a $30 \%$ lease fee discount, for marinas that are open to the public on a first come first basis. All revenues from the program are put into the Internal Improvement Trust Fund, which is used for conservation projects on Florida lands (Miller 1992).

Marina leases in Florida are currently granted for 5 year terms, although terms of up to 25 years are possible. Florida offered longer term leases after lenders became hesitant to accept a short term lease of 5 years. The Bureau still remains reluctant to grant 25 year leases, but will do so when serious financing problems occur. To iscourage marinas from requesting a long term lease, the 
Board requires marinas with longer than 5 year terms to pay additional fees (Ibid). For example, a 10 year lease is assessed an additional fee equal to the first year's annual fee. A 15 year lease is assessed an additional fee equal to one and a half times the annual fee, and 25 year leases are assessed an additional fee equal to two and a half times the annual fee. Only when the public interest in a marina is sufficient will Florida waive the lease fee and grant an automatic 25 year lease.

MARYLAND'S PROPOSED MARINA LEASING PROGRAM Like Rhode Island, Maryland is currently trying to implement a marina leasing program. Maryland has long asserted control over its submerged lands under the Public Trust Doctrine, and the Riparian Law Act of 1862 (Cassel 1989). The 1862 Act, prohibited Maryland from granting private entities fee simple title over submerged lands or tidal waters, nor could private rights be acquired in state owned submerged lands under the legal theories of prescriptive use or adverse possession (Ibid). The Riparian Act of 1862, remained the only law addressing submerged lands in Maryland, until the Wetlands Act of 1970 (Maryland Title 9-101 1990). The 1970 Act, did refer to submerged lands, but its main purpose was to cease the destruction of wetland areas by certain unregulated activities. The Act 
was amended in 1990, to include language that provides the foundation for Maryland to develop a marina leasing program. section 9-204 of the 1990 amendments allows that "the Board of Public Works may require as a condition to issuance of a wetlands license, that compensation be made to Maryland, of a kind and amount deemed appropriate by the Board". The amendment also set up a Wetlands Compensation Fund to receive revenues from the granting of wetlands licenses. The Act did grant the power to require license fees from marinas, but it only implemented fees for utility crossings, extraction of sand and gravel and structures on piers (Maryland Bill Report 1992) Although these amendments did not establish a marina leasing program, it was not long after the amendments that Maryland did propose such a program.

In 1992, the Governor's Commission on Efficiency and Economy recommended that annual lease payments be assessed by the Board of Public Works, for commercial and community marinas (Ibid). Funds from the marina leases are to be used to reduce dependence on general funds, used for the administration of the Tidal Wetlands Law. To enact the Commission's recommendations, a Bill was drafted to exclude marina lease payments from the Wetlands Compensation Fund, and established a new fund called the water Resources Operation and Management Fund. The Bill further authorizes 
the DNR and Board of Public Works to use marina lease revenues, for the administration and management of tidal wetlands. In the report issued on the Bill, the DNR found the assessment of lease payments on commercial and community marinas as justified, because the land on which these facilities were located is state owned submerged land. The Bill did not set up a lease fee payment structure, but left that function to the Board of Public Works, which has the authority to determine and assess fees on public lands. One interesting aspect of this proposal, is that an initial fiscal impact report done by the DNR's Boating Administration, estimated the lease program would generate $\$ 360,820$ annually. This figure was calculated by assessing a $\$ 10.00$ fee on all 36,082 slips currently located at commercial marinas in Maryland. This is the identical fee formula that Rhode Island tried to implement in its marina leasing program. At this time the Maryland Bill is still pending, but a marina leasing program seems to be likely in the near future.

\section{MICHIGAN'S MARINA LEASING PROGRAM}

Michigan has one of the oldest marina leasing programs in the United States. In 1955, Michigan passed the Great 
Lakes Submerged Lands Act, which gave authority to the State to lease marinas their submerged lands. The Act only applied to submerged lands in the Great Lakes, within the boundaries of the State of Michigan, which include Lake superior, Lake Michigan, Lake Huron, Lake St. Clair, and Lake Erie. The Act granted Michigan management authority over 38,504 square miles of Great Lake bottomland. Although Michigan has management authority over a large amount of submerged lands, its leasing program is limited. In Michigan a large amount of marinas exist on submerged lands which were granted to upland landowners prior to Michigan becoming a state. The granting of submerged lands to private landowners prior to statehood, is one of the few conditions in which public trust lands can be conveyed into private property. Section 322.705 of the Act established a marina leasing program, which is managed by the Department of Natural Resources Submerged Lands Management Unit (Michigan Submerged Lands Act 1955). With a leasing program that is almost 40 years old, Michigan has had a chance to establish thorough leasing requirements.

Michigan's marina leases contain the following standards. To address taxes, a condition of the marina leases, is that all lands leased under the Act shall be subject to taxation, and the general property tax laws as other real estate used and taxed by the governmental unit in 
which the marina is located (Ibid). On liability, there is a lease provision that states "the lessee agrees to hold Michigan harmless from any damage to persons or property that may arise due to the lease". The fee formula is the same system that Maine uses, and is calculated on a percentage of the slips gross revenues. Michigan now requires that marinas pay $5 \%$ of their gross slip revenues as a lease fee. The Act also established a maximum lease term of 50 years for marinas, with an automatic renewal option. In actual practice the state now grants 25 year leases, unless there a banking problem. To address problems with dockominiums, marinas must agree not to rent slips on a long term basis without the written permission from the state. The revenues from marina leases are sent to the General Treasures office, and put into the state General Fund, and In 1989, revenues from around 79 leases totaled $\$ 59.251 .00$ (Michigan Department Natural Resources 1989).

\section{SUMMARY}

This case review has demonstrated there is no common variable associated with a state establishing a marina leasing program. The review did show that a significant legal event as occurred in Rhode Island's Hall decision, has taken place in other states leading to the establishment of 
a marina leasing program. The review demonstrated that the type of lease fee formula, and conditions of the actual lease will influence how marinas except the plan. States with well organized plans did experience less opposition when trying to implement their programs. These case reviews have further shown that although the implementation of a marina leasing program is facilitated with a well organized program, Rhode Island should be prepared to allow the plan to evolve over time. 
CHAPTER 4 THE RESEARCH HYPOTHESES

When Rhode Island goes forward with a marina leasing plan, the type of lease fee formula implemented will play a critical role in the plan's success. Rhode Island must develop a lease fee system that is equitable to all marinas throughout the state. Such a formula must take into account factors like a marina's slip size and location if an equitable fee is to be determined. Rhode Island's current proposed marina leasing scheme would charge all marinas a flat rate of $\$ 10.00$ per slip. From Rhode Island's proposed plan two research hypotheses were developed as follows:

In Rhode Island's proposed management plan, size of marina's slips is not an equitable variable in determining a lease fee.

In Rhode Island's proposed management plan, location of marinas is not an equitable variable in determining a lease fee.

Under Rhode Island's proposed leasing plan all marinas would pay the same fee for use of state owned submerged land ( $\$ 10.00$ per $\mathrm{slip})$, regardless of their size or location. A standard flat fee is not equitable, because marinas receive significantly different incomes from their submerged lands, 
depending on factors such as their location and slip sizes. A review of other coastal states' marina leasing programs (TABLE 1) such as Florida, Texas, Maine, California, and Alabama's, revealed that their lease fees were calculated in a more proportional manner to the amount of income a marina would earn from its slips. The majority of these states calculate their fees based on the size of a marina's slips, or the percentage of income marinas receive from their slips.

Rhode Island's proposed marina leasing system fails to take into account the many variables that play a role in determining the wet slip price a marina may charge on submerged lands. Since marinas are hetrogenous, comparing the pricing structure and financial performance of marinas with different attributes is difficult. To levy an equitable fee, state planners must acknowledge these variables and attempt to develop a lease fee commensurate with factors such as a marinas size and location. Variables that are important in the determination of wet slip prices include the size of a slip, neighborhood characteristics of the marina, draft, and location (Pompe 1992). These variables play a significant role in determining a marina's overall income, as revenues from slip rentals return a $92 \%$ gross profit to marinas, and usually make up $25 \%$ of their total revenue (Comerford 1986). Slip fees are important to 
marinas, and it is a general rule in the marina industry, that slip fees should cover the mortgage held on the marina (Bell 1985). Two of the biggest variables that determine a marina's slip price are slip size and location of the marina.

To demonstrate the role that these variables can play in determining a marina's revenues, comparisons were done between slips at three marinas in Rhode Island. The marinas were selected from three different geographic areas, and include small, medium, and large marine businesses in Rhode Island. Point Judith Marina represents a small sixty slip facility located in Jeruselum. The medium size facility selected was Carlsons Marina located in Warwick, which has one hundred and eighty slips. Finally, Bend Boat Basin in Portsmouth, which is the largest marina in Rhode Island with three hundred and sixty slips was selected.

To confirm the first hypothesis, the income differences generated from slips of various sizes must be examined. First, the incomes generated from three slips of different sizes must be calculated. Next, the income totals on each slip will be compared to the flat $\$ 10.00$ lease fee a marina would pay under Rhode Island's proposed plan. These comparisons should demonstrate that Rhode Island's lease fee is inequitable in that it charges the same fee to all 
TABLE 1

MARINA LEASE SYSTEMS IN SELECTED STATES

STATE

FORMULA RATE

$\begin{array}{ll}\text { Alabama } & \$ .03 / \text { Square Foot } \\ \text { California } & 5-12 \% \text { Slips Gross Income } \\ \text { Florida } & \text { Tier } 1 \text { \$.0849/ Square Foot } \\ & \text { Tier } 27 \% \text { Slips Gross Income } \\ \text { Maine } & 4 \% \text { Slips Gross Income } \\ \text { Michigan } & 5 \% \text { Slips Gross Income } \\ \text { Mississippi } & \$ .07 / \text { Square Foot } \\ \text { Oregon } & \$ 418.00 \text { lst Acre/ } \$ 215.00 \text { Remainder } \\ \text { South Carolina } & \$ 500.00 \text { One Time Fee } \\ \text { Texas } & \$ 3.00 / \text { Linear Foot }\end{array}$

TABLE 2

SLIP FEE FOR VARIOUS SIZE BOATS

SIZE OF BOAT

PRICE PER FOOT

TOTAL COST

$\begin{array}{lll}25 & \$ 80.00 & \$ 2000.00 \\ 45 & \$ 80.00 & \$ 3600.00 \\ 140 & \$ 80.00 & \$ 11,200.00\end{array}$

* Current Rate at Wickford Shipyard $\$ 80.00$ per Foot 
marinas even though they may generate significantly different incomes on their slips.

In marina operations marinas base slip fees on the length of dock space a boat occupies, or the length of the boat, whichever is greater. A marina that can accommodate larger boats, will generate more income per slip. The size of boats a marina can accommodate varies with each marina, due to factors such as draft, and available dock length. At this time, Rhode Island recreational marinas have the potential to dock boats up to 140 feet (Goat Island 1994). Rhode Island's plan is inequitable in that by charging the same $\$ 10.00$ lease fee per slip to all marinas, the state is asking marinas that generate substantially different incomes per slip to pay the same fee. This is demonstrated in TABLE 2 where revenues from a 140 foot, 45 foot, and a 25 foot slip are compared at a typical Rhode Island marina rate of $\$ 80.00$ per foot. The comparisons show a $\$ 7,600.00$ difference in revenues between the $\$ 11,200.00$ a marina would receive on a 140 foot slip, and the $\$ 3,600.00$ it would receive on a 45 foot slip. When the 140 foot slip is compared to the 25 foot slip, an even greater difference of $\$ 9,200.00$ is realized. These comparisons show that large economic differences exist, between the possible revenue amounts marinas can generate from their slips. The basis for the thesis hypotheses, was that it is inequitable for 
Rhode Island to extract the same rent from leases that generate significantly different incomes. The comparisons between slips of different sizes demonstrates, that Rhode Island's proposed plan would be inequitable, by applying the same fee to all slips, even though many generate different incomes. This comparison further assumed that all marinas charge the same slip fee of $\$ 80.00$ per foot. Applying a standard slip fee to all marinas is inapplicable in real marina operations, because a marina's slip rates will vary to a large extent depending on other variables such as location.

To prove the second hypothesis, it must be confirmed that the location of a marina is a variable that is not given consideration under Rhode Island's proposed plan. It must be established that a marina's income may differ depending on where it is located. By calculating income from a thirty foot slip located at three marinas in Rhode Island, it can be established that slip revenue can fluctuate depending on location. Incomes from these slips can then be compared against Rhode Island's flat fee system to demonstrate how location is not an equitable variable under Rhode Island's proposed plan. This should reveal that marinas with the same size slips will pay the same lease fee even though they can generate different incomes depending on where they are located. 
Next, the function of a marinas location in relation to its slip price will be examined. This will be accomplished by examining a few of the factors that help determine why location can influence a marinas wet slip price. These elements will then be applied to the three marinas previously selected for comparisons. The role location plays in determining a marinas wet slip price is complex, and this thesis will only examine three of the possible variables involving location and pricing.

In Rhode Island, the explosive growth of the number of boats during the 1960s and 1970s, brought about a proliferation of marinas (Lee and olsen 1980). At this time there are virtually no sites left in the lower and mid-Bay where a new major marina could be built (Lee and olsen 1980). This limits the possible areas where marinas can be located in Rhode Island to their present sites.

To confirm slip price variations due to location, 30 marinas throughout Rhode Island were randomly selected and surveyed by telephone, for their slip fee on a thirty foot boat. The marinas selected are found in most of the possible geographic areas where marinas are located in Rhode Island. As Table 3 demonstrates, marina's slip prices varied with respect to the different locations. To confirm variation in incomes due to location, a comparison of slip revenues for a thirty foot boat was calculated on two of the 
selected marinas. As shown in Table 3, Carlsons Marina currently charges $\$ 65.00$ per foot for a thirty foot slip, compared to $\$ 80.00$ a foot for a thirty foot slip at Pt. Judith marina. When revenues from the slips are calculated, a thirty foot slip at Pt. Judith generates $\$ 2,400.00$ compared to $\$ 1,950.00$ for a thirty foot slip at Carlsons. This difference suggests that Pt. Judith receives $\$ 450.00$ more than Carlsons for use of the same amount of state land. This variation in marina incomes would become even more apparent from location, if revenue differences were multiplied by the amount of slips each marina contains. These price variations demonstrate that Rhode Island's current proposed lease fee of $\$ 10.00$ per slip, would be inequitable if charged to all marinas located throughout the State. Again these comparisons show that marinas would be paying the same lease fee on submerged lands, that generate different incomes. By requiring all marinas to pay the same lease fee per slip, Rhode Island may also inadvertently give marinas in higher priced locations an economic advantage. This problem may not occur if the total cost of the state's lease fees are passed on to consumers, through higher slip rates.

To understand why a marina's location affects its slip pricing, you must examine some of variables associated with wet slip pricing. When choosing a marina most boat owners 
TABLE 3

CURRENT SLIP RATE FOR 30 FOOT BOATS AT RHODE ISLAND MARINAS

\begin{tabular}{lcc}
\hline MARINA & TOWN LOCATED & PRICE PER FOOT \\
IN DOLLARS
\end{tabular}

\begin{tabular}{|c|c|c|}
\hline Angels & Warwick & 55.00 \\
\hline Apponaug Harbor & Warwick & 55.00 \\
\hline Avondale & Westerly & 65.00 \\
\hline Bay & Warwick & 59.00 \\
\hline Bend Boat basin & Portsmouth & 85.00 \\
\hline Block Island Boat Basin & Block Island & 80.00 \\
\hline Brewers Sakonnet & Portsmouth & 72.00 \\
\hline Brewers Wickford Cove & Wickford & 82.00 \\
\hline Brewers Yacht Yard & Warwick & 82.00 \\
\hline Bullock Cove & East Providence & 55.00 \\
\hline Carlsons & Warwick & 65.00 \\
\hline Channel & South Kingston & 60.00 \\
\hline C-Lark & Warwick & 60.00 \\
\hline Cove Haven & Barrington & 65.00 \\
\hline Goat Island & Newport & 95.00 \\
\hline Greenwich Cove & East Greenwich & 65.00 \\
\hline Harborlight & Warwick & 58.00 \\
\hline Kenport & Matunuck & 60.00 \\
\hline Lavins & Barrington & 60.00 \\
\hline Newport Yachting Center & Newport & 88.00 \\
\hline
\end{tabular}


TABLE 3 CONTINUED

CURRENT SLIP RATE FOR 30 FOOT BOAT AT RHODE ISLANDS MARINAS

\begin{tabular}{llc}
\hline MARINA & TOWN LOCATED & $\begin{array}{c}\text { PRICE PER FOOT } \\
\text { IN DOLLARS }\end{array}$ \\
Ocean House & Charlestown & 60.00 \\
Pirate Cove & Portsmouth & 65.00 \\
Point Judith & South Kingston & 80.00 \\
Ram Point & Wakefield & 65.00 \\
Stanleys Boat Yard & Barrington & 61.00 \\
Silver Spring & South Kingston & 75.00 \\
Stone Cove & South Kingston & 55.00 \\
Treadway & Newport & 85.00 \\
Westerly & Westerly & 50.00 \\
Wickford Shipyard & Wickford & 80.00
\end{tabular}

Marinas were randomly selected then contacted by phone 
seek marinas near their homes, to minimize costs and travel time (Lyon 1967). As boat owners have a higher average household income than non-boat owners, it can be expected that marinas in towns where the per capita incomes are higher will command higher slip prices (Bell 1990). A comparison of the three selected marinas' (Table 4) slip prices, and household values of the towns there located in corroborates this characteristic. Carlson's marina which has the lowest slip price of the three selected marinas is located in Warwick, Rhode Island. A review of the recent U.S. Census economic figures shows that Warwick has the lowest average household income $(\$ 35,786)$, and house value $(\$ 116,000)$ of the three locations (U.S. Census 1990). Pt Judith marina which is located in South Kingston, Rhode Island has the next highest slip prices, associated with the next highest house value $(\$ 158,000)$ and a slightly higher household income $(\$ 36,481)$. The last marina, Bend Boat Basin located in Portsmouth, Rhode Island has the highest slip price associated with the highest household income $(\$ 42,474)$, and house value $(\$ 168,000)$. If marinas in towns with higher incomes do generate greater revenues from their slips, that factor is not taken into account in Rhode Island's proposed marina leasing plan. This further demonstrates that Rhode Island's marina leasing plan as proposed would be inequitable. 
TABLE 4

HOUSEHOLD VALUES AND INCOMES FOR TOWNS OF THREE SELECTED MARINAS

\begin{tabular}{lrrr}
\hline $\begin{array}{l}\text { TOWN MARINA } \\
\text { IS LOCATED }\end{array}$ & MARINA'S FEE & AVERAGE & AVERAGE \\
& PER FOOT & FAMILY INCOME & HOUSE VALUE \\
Portsmouth & $\$ 85.00$ & $\$ 42,474.00$ & $\$ 168,000.00$ \\
South Kingston & $\$ 80.00$ & $\$ 36,481.00$ & $\$ 158,000.00$ \\
Warwick & $\$ 65.00$ & $\$ 35,786.00$ & $\$ 116,600.00$
\end{tabular}

Household Values and Incomes are from U.S.

Department of Commerce 1990 Census 
The neighborhood characteristics of a marina's location is another variable that affects wet slip pricing (Pompe 1992). Even a marina with a prize winning design will fail if it is not located near shopping areas, restaurants, and other service areas its customers patronize (Rogers 1982). Marinas found in areas that have waterfronts containing fine restaurants, live entertainment, and shopping districts charge higher slip fees (Pompe 1992). Bend Boat Basin, which charges the highest slip fees of the three selected marinas, corroborates this point. Bend's markets itself as being close to Newport, Rhode Island, a popular tourist spot and international yachting center (Bend 1994). Bends marketing brochure proclaims that it has a superb location, since it is located just 6 miles north of Newport, which it asserts is abundant with shops, restaurants, and seasonal festivals. By comparison, Carlson's marina, with the lowest slip price, is located the furthest distance from a popular waterfront. The immediate waterfront surrounding Carlson's, is void of fine restaurants and shopping districts, and primarily consists of residential homes. Located near a popular commercial shellfish purchaser, Carlson's also retains a small amount of slips for commercial shellfishermen, a factor which may make the marina less appealing to recreational boaters. The last of the three marinas Pt. Judith marina, is found in South Kingston, Rhode 
Island, a popular seasonal tourist resort. Marinas in seasonal tourist areas charge higher slip fees, due to their location (Bell 1990). Pt Judith marina may appeal to boaters, because of its close proximity to Rhode Island beaches, and tourist havens such as Galilee, and Block Island. Neighborhood characteristics are just one of the many variables that influence a marinas wet slip price not taken into account in Rhode Island's proposed plan. Other variables not considered in this thesis would need to be examined to explain why stone Cove marina although located in the vicinity of Point Judith marina only charges $\$ 55.00$ a foot. With such a large the amount of variables associated with wet slip pricing, it even more critical that Rhode Island develop a lease fee formula that is fair to all marinas.

Access to open water and popular sailing and fishing sites, can also influence a marina's slip pricing (Rogers 1982). The three marinas selected for comparisons are located in different geographic areas inside and outside of Narraganset Bay. Of the three marinas, Pt. Judith offers the most convenient access to open water, and that is a convenience sportfishermen are willing to pay for. By docking a boat at Pt. Judith, a sportfisherman can save time and fuel associated with traveling to popular Rhode Island offshore fishing sites, such as Coxes Ledge and the Dump. 
By comparison, a sportfisherman docking at Carlsons marina would average another hour in travel time, when traveling to the same location. When sportfishermen add in potential fuel costs associated with reduced travel time, the increased cost of docking at Pt. Judith marina over Carlson's may become insignificant. Sailboat mariners who wish to reduce sail time to popular sites such as Cuttyhunk, Block Island, and the Cape, may also be willing to pay extra for a convenient water access location.

\section{A COMPARISON OF LEASING FORMULAS}

To demonstrate the revenue differences a lease formula can generate, three lease formulas were selected and computed on a model marina. The revenue amounts from these formulas will then be compared to Rhode Island's proposed fee scheme, to demonstrate the incomes each formula would generate. These formulas represent the three most common fee structures used in marina lease fee evaluations in the United states. The three systems are Florida's base fee linear foot method, Texas's square foot method, and Maine's recently adopted percentage of slip revenue method.

In 1991, the Maine Legislature added amendments to its submerged lands lease provisions, which establish a different formula for calculating lease fees for marinas (Maine Law Institute 1991). Maine implemented the new 
method, after numerous marinas complained that the old upland tax evaluation method, resulted in extremely different lease fees for similar facilities. Rhode Island's proposed marina leasing plan has the potential to do the exact opposite. It would result in all marinas paying the exact same fee, even though their facilities are extremely different. If Rhode Island implements the proposed plan, it should anticipate complaints such as Maine received, claiming that the lease rate is inequitable.

To illustrate and compare the revenue differences between the three leasing formulas, a model marina was developed. The marina model was developed from a previous model used by the Marina Association of Texas to evaluate coastal dredging and marina fees (McKann 1987). The model marina is comprised of 141 slips, with a total dock length of 4915 linear feet, and covers 126,097 square feet of submerged land. This model bears a close resemblance to Wickford Shipyard Marina, which is located in North Kingston, Rhode Island (Ross 1988). The total amount of submerged land area in the model should resemble Wickford Shipyard's as both have similar slip sizes and an identical slip capacity of 141. Although not exact, the lease fees generated from these formulas would be close to the actual amount that wickford Shipyard would pay, if Rhode Island adopted one of the formulas. 
The first formula to be computed will be Texas' linear foot system. This formula charges marinas an annual leasing fee of $\$ 3.00$ per linear foot, for each foot of dock space leased (Texas Land Commission 1991). The model marina estimated that a 141 slip marina, with an average slip size of 35 feet, would have a total of 4915 linear feet available for rent. As shown in TABLE 5, a marina being charged by this formula would pay an annual lease fee of $\$ 14,745.00$ to the state. To make a comparison, Rhode Island's proposed fee of $\$ 10.00$ per slip was also calculated on the model marina. At $\$ 10.00$ per slip the total cost for a $141 \mathrm{slip}$ marina would be $\$ 1,410.00$. When total lease fees from Rhode Island and Texas are compared, a marina leased under the Texas rate pays an additional $\$ 13,335.00$ in fees.

The next formula to be calculated is Florida's base fee system, which charges a lease fee based on the amount of square feet of submerged land a marina occupies. At this time Florida charges marinas an annual fee of $\$ 0.0849$ per square foot (Florida Division Natural Resources 1992). The model marina estimated that a 141 slip marina would cover a total of 126,097 square feet of submerged land (McKann 1987). As shown in TABLE 5, a marina charged by this formula would pay an annual fee of $\$ 10,705.00$ to the state. To demonstrate the revenue differences, this fee was again compared to the amount generated by Rhode Island's proposed 
plan. When total lease fees for each plan are compared, a marina under Florida's plan would pay an additional $\$ 9,295.00$ more in lease fees than it would under Rhode Island's proposed rate.

Maine's lease fee formula was the last to be calculated. This formula charges a lease fee based on the percentage of revenue a marina generates from its slips. Maine's system still bases fees on the fair market value of the submerged land. Maine now considers fair market value to be a percentage of the total annual income from a marina's slips (Maine Law Institute 1991). For recreational marinas the rate is $4 \%$ of the annual income from their slips, and for commercial marinas $2 \%$ of the annual income from their slips. Under Maine's system lease fees would fluctuate annually, depending on the yearly gross income of the marina. For the model marina a rate of $\$ 80.00$ per foot was used, as this is the current slip rate of Wickford Shipyard Marina. The annual income of the marina was estimated at full capacity, with 4915 feet of slip space rented, at $\$ 80.00$ per foot. As shown in TABLE 5, a marina under this system would pay an annual lease fee of $\$ 15,728.00$. Once again, this rate was compared to Rhode Island's proposed rate, and as with the other lease systems, a marina being charged by Maine's formula would pay an additional $\$ 14,318.00$ to the state. 
These comparisons show that Rhode Island's proposed plan would charge marinas the lowest lease fee, and thus generate the lowest overall income for the state. If Rhode Island adopted any of the other three formulas, it would substantially increase the revenue amounts it received from a marina leasing program. If the projected lease fees of the three formulas are too high, Rhode Island could simply adjust the formulas to reduce the rate. For example, instead of charging Texas' rate of $\$ 3.00$ per linear foot, the state could charge $\$ 1.00$ per linear foot, thus reducing a $\$ 14,745.00$ lease fee by $1 / 3$ to $\$ 4,915.00$. The same principle applies to Florida's and Maine's systems, where total lease fees could be reduced by adjusting the formula rates.

When selecting its formula, Rhode Island should adopt the rate that is equitable to all marinas regardless of their slip size or location. All three of the selected leasing formulas would make slip size a more equitable variable in determining a marina's lease fee. Two of the formulas, linear foot and square foot, directly base their lease fees on the size of a marina's slips. A marina with 100 slips that average 45 feet would pay a larger lease fee to Rhode Island, than a marina with 100 slips averaging 25 feet. These formulas calculate the rate based on the actual amount of area leased. That enables marina's lease fees to 
TABLE 5

LEASE RATES ON MODEL MARINA FROM THREE SELECTED STATES AND RHODE ISLAND

\begin{tabular}{lccc}
\hline STATE & LEASE FORMULA & $\begin{array}{c}\text { MODEL MARINA } \\
\text { TOTALS }\end{array}$ & TOTAL FEE \\
TEXAS & $\$ 3.00$ LINEAR FOOT & 4915 & $\$ 14,745.00$ \\
FLORIDA & $\$ 0.0849$ SQUARE FOOT & 126,097 & $\$ 10,705.00$ \\
MAINE & $4 \%$ SLIP INCOME & $\$ 344,050$ & $\$ 15,728.00$ \\
RHODE ISLAND & $\$ 10.00$ PER SLIP & 141 & $\$ 1,410.00$
\end{tabular}

Fees were calculated on model marina developed by Marina Association of Texas

Wickford Shipyard's Slip Rate of $\$ 80.00$ per Foot used to calculate Maine's Formula 
be determined more in proportion to the actual amount of revenues generated from their submerged lands, and thus be more equitable to marinas.

The last method, Maine's percent of the slip revenue formula, is the most equitable formula presently available. Marinas charged according to this formula would pay the same proportion of their income to the state as a lease fee, regardless of where the marina is located or how big its slips are. This formula would address the problems identified in the hypotheses by disregarding both size and location as factors in determining a lease fee. A large marina located in Newport, Rhode Island that charges $\$ 90.00$ per foot, would pay the same proportion of its slip revenues (4\%), as a small marina located in Warwick, Rhode Island charging $\$ 55.00$ per foot. By charging a marina this rate, Rhode Island would also equally distribute any economic hardships caused from the leasing fees. This method should also be more acceptable to the marina industry, as it would be adjusted to reflect the marina's fiscal year. In years where marina revenues are down because of empty slips, the lease fee could be reduced to reflect that. This is unlike the square foot, linear foot, or Rhode Island's proposed flat rate method, where lease fees would remain the same regardless of the marina's economic condition. 
For state agencies like Rhode Island's CRMC this system may have some negative consequences. First, this type of system would have to be continually monitored and adjusted by the CRMC as totals would change year to year. Furthermore, many state agencies depend on revenues from programs like marina leasing to pay their operational costs. If marinas suffer an economic slump, revenues from leasing fees could be expected to decrease, thus affecting the agency's budget. 
CHAPTER 5 POTENTIAL PROBLEMS IN IMPLEMENTING RHODE ISLAND'S MARINA LEASING PLAN

\section{HARBORLINE ACTS AND MARINA LEASING}

Following statehood and the ratification of the United states Constitution, the Rhode Island General Assembly slowly started to declare its authority over state waters and the adjacent tidelands which were not yet developed (Nixon 1990). The practice of filling tidelands became a popular method to create waterfront property in Rhode Island, and without state regulations, many harbors would have been filled in by riparian landowners. In 1815, Providence Rhode Island moved to establish some control over its submerged lands by passing the first harborline act (Ibid) - The harborlines primarily served to control the filling of tidelands in Narraganset Bay, and maintain the right to freely navigate protected by the navigational servitude. Navigational servitude is the paramount right of the Federal government or States, to compel the removal of any obstruction to navigation, without paying just compensation which the Fifth Amendment ordinarily requires (Kalo 1990). From 1815, to the creation of CRMC in 1971, harborlines served as the only factor regulating marina and wharf development in Rhode Island. Harborline acts may prove to be problematic for Rhode Island, if they are found 
to be legislative grants. Legislative grants are one of the few valid legal methods by which public trust submerged lands can be conveyed to a private party.

In the Rhode Island Supreme Court case of Engs V. Peckham, 11 R.I. 210 (1875), the court found that the creation of a harborline is equivalent to being granted a license to wharf out to that line. Marinas that were constructed behind these legislatively created harborlines, may claim they were granted a legislative license predating the CRMC's creation in 1971. Furthermore, marinas could claim that the harborline acts granted them a legislative license to build marinas and wharfs out to that line, and that under the rule of licenses Rhode Island may not initiate a leasing program. This could make Rhode Island's situation somewhat different from the Brusco case. In Brusco, the court found that marinas existed under a passive or implied license, which is a revocable privilege the legislature can revoke at any time. In Rhode Island, marinas may claim that a legislatively created license is different than a passive or implied license, and that the right can not be taken away without compensation under the rule of licenses.

Another important question the Court may need to decide is does the creation of a harborlines qualify as a legislative grant. If harborlines are considered a 
legislative grant, then marinas will claim that the lands on which their structures are located were legally transferred to them. If this claim is found to be valid, it would impact marinas in Newport and Providence where the two legislatively created harborlines are located. That would have a major impact on Rhode Island's income potential from any marina leasing program, as 1200 of the 10,000 estimated slips in Rhode Island are located in Newport or Providence harbor. In making such a decision, the Rhode Island courts will have to look back at the Engs decision, and decide whether harborlines constituted more than just a license. In Engs, the Rhode Island supreme court did find that harborlines are equivalent to a legislative declaration. If such a declaration is found to be equivalent to a grant, then the marinas have a valid claim to their submerged lands. As this issue has not been brought before a Rhode Island Court in the past, it is unclear how the courts would decide such a case.

If marinas fail in claiming that harborlines granted them the titles to their lands, they may claim that harborlines created a specific property right, which does not conflict with the principles of the Public Trust Doctrine. As long as marinas provide the public service of water access, they could claim that they pass the public trust conditions of the Doctrine. This condition would 
apply more to public marinas, rather than private yacht clubs or marinas closed to the public. If Rhode Island Courts consider the question of public and private rights, they will have to decide what such rights were granted by the harborline acts, and if such rights were granted, can they now be extinguished. If the courts look at Vermont and City of Burlington V. Central Vermont Railway, 571 A.2d 1128 (vt. 1989), and decide that harborlines are parallel to the legislative grants given vermont Railroad. They may then they may conclude that a property right does exist, as long as marinas are open to the public. The court will then have to decide, as the Oregon Supreme Court did in Brusco Towboat v. State of oregon, 589 P.2d 712, (Or. 1978), whether or not using state owned submerged land is a right that can be taken away without compensation. In Brusco, the oregon Supreme court found that no property rights existed in submerged lands that could not be revoked by the legislature. Depending on the outcome of such a decision, it may take another legislative action by the Rhode Island General Assembly to abolish any property rights created by harborlines.

\section{TERMS OF A LEASE FOR MARINAS}

When Rhode Island moves forward with a marina leasing program, the state must consider the length of the lease, 
along with renewal requirements. Rhode Island Statute 4623-16 presently allows the Coastal Resource Management Council (CRMC), to grant marinas licenses for any term of years or in perpetuity (RI CZMP 1983). At this time, the CRMC grants marinas licenses on their submerged lands for 50 year terms. In Rhode Island, the terms of a marina's lease should be well defined before implementation of a marina leasing program.

Lease renewals should also be addressed, as the current Rhode Island Coastal Resource Management Plan does not contain criteria for renewals. This may be because the CRMC grants 50 year licenses, none of which will expire in the near future.

One problem states' have encountered with lease terms is that a short term lease can create difficulties in marina financing. As shown in TABLE 6 , the states that encountered difficulties with lenders are Florida, Texas and New Jersey, all which grant relatively short term leases. In some instances, short term leases of under 20 years have made construction of new marinas or improvements to existing marinas virtually unfinanceable. On TABLE 6 , a list of various coastal states' lease terms is given, including states where term limits currently do not exist.

In Massachusetts, where a 30-year license term was recently enacted, the state received powerful opposition 
over the length. Commercial interests in Massachusetts were concerned that as a marina gets closer to the end of its lease, or faces a renewal, banks may not be willing to grant loans on the property. Furthermore, banks may become increasingly less unwilling to refinance or commit to loans for improvements to marinas. Banks could further request unrelated collateral to be reasonably assured of repayment on their loans. That potentially could lead to underinvestment and deterioration of existing marinas. Banks may also demand shorter loans on marinas with short term leases. This could result in unmanageable cash flows for marinas in the first few years of business.

In New Jersey, marina leases have gradually started to be extended from 5 to 20 years, after commercial bank lenders became concerned with the stability of a 5-year lease. To provide for the loans, marinas have requested leases over 30 years, but the state still refuses to consider anything over 20 years. New Jersey lease terms now vary from marina to marina, and leases are negotiated by the Attorney General's office, the Tidelands Council and the marina owner (Massachusetts Report 1987). Banks in New Jersey have also shown concern about the amount of lease fees levied on marinas. Banks were concerned that if the fee structure is of a certain magnitude, it could affect the marina's financial operations, thus impacting a loan. 
TABLE 6

Marina Lease or License Terms in Selected States

\begin{tabular}{|c|c|c|c|c|}
\hline STATE & Lease & License & $\begin{array}{c}\text { Typical } \\
\text { Term }\end{array}$ & $\begin{array}{l}\text { Maximum } \\
\text { Term }\end{array}$ \\
\hline Alabama & & $\mathrm{x}$ & 3 & 3 \\
\hline California & $\mathrm{x}$ & & 25 & 49 \\
\hline Connecticut & & $\mathrm{x}$ & \multicolumn{2}{|c|}{ Unlimited } \\
\hline Florida & $\mathrm{x}$ & & 5 & 25 \\
\hline Louisiana & $\mathrm{x}$ & & 5 & 5 \\
\hline Maine & $\mathrm{x}$ & & 30 & 30 \\
\hline Michigan & $\mathrm{x}$ & & 25 & 25 \\
\hline Mississippi & $\mathrm{x}$ & & 40 & 40 \\
\hline New Hampshire & & $\mathrm{x}$ & \multicolumn{2}{|c|}{ Unlimited } \\
\hline New Jersey & $\mathrm{x}$ & & $5 / 20$ & 30 \\
\hline New York & $\mathrm{x}$ & & 10 & 25 \\
\hline Oregon & $\mathrm{x}$ & & 20 & 40 \\
\hline Rhode Island & & $\mathrm{x}$ & 50 & 50 \\
\hline Texas & $\mathrm{x}$ & & 20 & 99 \\
\hline Virginia & $\mathrm{x}$ & & 5 & 5 \\
\hline & & $\mathrm{x}$ & \multicolumn{2}{|c|}{ Unlimited } \\
\hline Washington & $\mathrm{x}$ & & 15 & 35 \\
\hline
\end{tabular}


Texas is another state that has moved towards longer term leases due to pressures from the banking industry. In Texas, marina leases are currently granted for 20 year terms, but on larger marina projects (200-300 slips) longer terms of 30 to 50 years are becoming available (Ibid). Texas will even consider a lease of 99 years if the project is large enough and requires a substantial investment.

In Florida, terms of marina leases have constantly changed over the last 16 years (Florida Submerged Lands Plan 1993). Until 1977, Florida granted annual licenses that were considered renewable in perpetuity. In 1977, the state went to a 25-year lease to avoid problems with lenders. Currently, Florida has returned to granting leases for 5 year terms, although 25 year leases are still possible (Florida General Laws 18-21 1990). Decisions on lease terms are made by the Governor and Cabinet, sitting as the board of trustees. In the past they have shown a reluctance to grant longer term leases, unless they are in the public interest. An example of where a 25-year lease would apply is a municipality that needs a lease for a major waterfront development project.

Another issue involving lease terms is that of standards to be applied for lease renewals. Rhode Island must decide if leases will be automatically renewed, or if some criteria should apply for the lease to be renewed. It 
can be expected that marinas will prefer automatic lease renewals to address concerns that banks may have, and guarantee stability. Furthermore, within the time frame of a lease, Rhode Island must decide when the lease fees will be considered for adjustment. The review of other State's leasing plans showed renewal standards vary, though most states apply some type of criteria. Maine leases currently run for 30 years, and lease renewals are left up to the Director of the Bureau of Public Lands (Maine Submerged Land Rules 1992). When considering renewals, the Director looks at factors such as public interest, policy conflicts and any history of noncompliance. In California where leases can run up to 49 years, automatic renewals were once standard, but now are no longer offered. California leases may include a renewal option, but most applicants for renewals are treated like new applications and are dealt with on a case by case basis (California General Laws 1990). California now takes control of the leased submerged lands after the lease runs out, and considers any improvements done on the land as their property. This works like a basic landlord tenant law, where a tenant builds a built-in bookcase in an apartment and then moves out. The bookcase becomes the property of the owners. It should be expected that any law that declares the state as owner of property 
improvements will meet strong resistance from private property holders.

The amount of public access granted by a marina should also be a factor in its lease renewal. Many states consider public access a key requirement when considering lease renewals. Marinas restricting public access should be charged higher fees, or have their renewals subject to providing some type of public access.

\section{PROBLEMS WITH TAXES ON SUBMERGED LANDS}

Taxes are another issue that must be resolved, before Rhode Island implements its marina leasing program. Title claims over taxes involving submerged lands, have been addressed previously in both the state and Federal courts. Submerged land owners have claimed that the act of paying taxes on their property establishes title. If that challenge fails, marinas can be expected to request that their properties be reevaluated. Marinas will request that any value created by the adjacent submerged lands be subtracted from their tax appraisals. There is also a possibility that municipalities will try to increase marina's taxes by reappraising marina's submerged lands as if they were owned fee simple. This practice recently began in Florida, and as more towns undergo budget deficits it may 
become a common practice (Flannery 1993). Tax problems are something that Rhode Island should be able to avoid, if a tax policy is set at the beginning of its leasing program. The claim that paying taxes on submerged lands establishes title is not new to the courts. In phillips Petroleum Company V. Mississippi, 484 U.S. 469 (1988), petitioners claimed that taxes were paid on the submerged lands in question, under a reasonable expectation of a property interest. Phillips claimed that their continuous payments of property taxes had relinquished Mississippi's ownership under the Doctrine of Laches, or another equitable doctrine. Laches is the Doctrine that signifies an undue lapse of time in enforcing a right of action, and negligence in failing to act more promptly (Gifis 1984). It recognizes that because of the delay the defendant's ability to defend may be unfairly impaired, because witness or evidence needed to defend against the stale claim may have become unavailable or lost. The Doctrine of Laches also recognizes, that if the delay has led the adverse party to change his or her position as to the property or right in question, it is inequitable to allow the negligent delaying party to be preferred in their legal right. In Phillips, the U.S. Supreme Court agreed with Mississippi's Supreme Court, that tax payments have no affect on the title to submerged lands. The Supreme court further agreed with the 
Mississippi supreme Court in finding that the state's ownership of the submerged lands can not be lost via adverse possession, Laches, or any other equitable doctrine phillips Petroleum Company V. Mississippi, 484 U.S. 469 (1988). How a Court decides such an issue will depend on the state in which the case is being held, because under the U.S. Constitution, the law of real property is left to the individual states to administer (Kalo 1990). In Rhode Island, the outcome of such a title case would most likely be similar to Phillips. Rhode Island real estate law has a provision that private individuals cannot adversely possess shoreline or waterfront property located within the state, because such property is maintained for public use (Rhode Island General Law 19561984 Reenactment 34-7-8). If the Rhode Island Courts decline to find that paying taxes on submerged lands establishes adverse possession, it is likely they would find other equitable doctrines would also not apply to paying taxes.

Another challenge regarding taxes was made in state of Vermont and City of Burlington v. Central Vermont Railway, 571 A.2d 1128 (Vt.1989). Like Phillips in Central Vermont Railroad the plaintiffs claimed that the action of paying taxes on the lands at issue invoked the Doctrine of Laches barring any claims made by Vermont. The vermont supreme Court decided the case in a way similar to the U.S. Supreme 
Court's decision in Phillips, and stated, "We hold that the claims asserted cannot be barred through either Laches or Estoppel". The Court then went even further when it stated, "The Doctrine of Equitable Estoppel is rarely invoked against the government, being allowed only where the injustice that would otherwise result is of sufficient magnitude, to justify any effect that the Estoppel would have upon public interest or policy". This decision further signifies that any claims brought against Rhode Island on similar grounds will probably be decided in the state's interest.

Rhode Island should also be prepared for a request from marina owners seeking a reappraisal of their properties. Marinas would claim that their current tax appraisals are incorrect, because the values are based on their ownership of the adjacent submerged lands, on which Rhode Island as fee simple holder is now charging them a lease fee. This claim would concern cities and towns containing marinas since any changes in tax appraisals would affect their real estate tax revenues.

To demonstrate how a town may lose tax revenues, Carlson's Marina located in Warwick, Rhode Island will have its uplands reevaluated using Maine's upland evaluation method. Carlson's submerged lands will be appraised at $20 \%$ of its uplands value. This number (20\%) was developed in 
Maine by a committee of the Bureau of Public Lands of the Department of Conservation (University of Maine 1991). The committee was established to review Maine's lease fees and study waterfront values. The committee recommended modification of the fee system to more clearly favor commercial water dependent uses, and to yield fair compensation to the public. The committee further established that marina's submerged lands should reflect the adjacent upland value. Instead of requiring separate appraisals to determine the value of each marina site, the Committee recommended that the Bureau accept each towns assessed value of the adjacent upland as an approximation of the value of the submerged lands. This value would then be adjusted to reflect the proposed use of each site. Submerged land used for commercial fisheries were deemed to be worth $10 \%$ of the uplands value, while other water dependent uses were valued at $20 \%$ of the upland's value. For submerged lands that were not utilized for water dependent uses, the lands were valued at $100 \%$ of the upland's value. Under this system recreational marinas would be assessed at $20 \%$ of adjacent upland value.

As shown in TABLE 7, Carlson's Marina's uplands were assessed for $\$ 376,200$ by the city of Warwick in 1992. If the submerged lands are valued at $20 \%$ of the marina's adjacent uplands, they would be valued at $\$ 75,240$. When 
subtracted from the marina's original value of $\$ 376,200$, the new assessed value of Carlson's uplands would be $\$ 300,940$. At the current Warwick tax rate of $\$ 31.00$ per $\$ 1,000.00$, this would mean a loss of $\$ 2,332.44$ in tax revenues to warwick. Such reductions in towns tax revenues could add up to a significant amount, especially in towns like warwick where 23 marinas exist (Ross 1988). If marinas are successful in receiving tax reductions, cities and towns can be expected to turn to the state of Rhode Island to compensate them for the lost revenues.

While marinas may seek a reduction in their taxes if Rhode Island implements a marina leasing plan, it is also possible that municipalities will target marinas' submerged lands as a source of additional tax revenue. Again using Maine's appraisal system, where the submerged lands equal $20 \%$ of the uplands value, Carlson's Marina's was reevaluated. As illustrated in Table 7, Carlsons new value would climb by $\$ 75,240$ to $\$ 451,440$. That new value would increase Warwick's real estate tax revenues by $\$ 2,332.44$. This type of action could generate substantial amounts of revenues for towns, but represent a substantial new burden on marinas.

Taxing marinas on their submerged lands was recently undertaken in Brevard County, Florida, when marinas were given new tax appraisals on their properties, with their 
TAX ASSESSMENTS OF CARLSON'S MARINA UNDER MAINE'S UPLAND VALUE METHOD

\begin{tabular}{lcc}
\hline Upland Value & Assessed Value & Assessed Value \\
1992 Warwick RI & Increased by $20 \%$ & Decreased by $20 \%$
\end{tabular}
$\$ 376,2000$
$\$ 451,000$
$\$ 300,940$

Taxes in Warwick Rhode Island are currently assessed at $\$ 31.00$ per $\$ 1000,00$

Under Maine's Upland Value Method submerged lands for recreational marinas are assessed at $20 \%$ of the adjacent uplands value 
submerged lands being appraised at $\$ 4.00$ a square foot (Flannery 1993). The new taxes tripled one small 50 slip marina's real estate taxes to $\$ 8,000.00$. Charging real estate taxes on government leased lands started in Florida after a 1988 decision, involving the orlando Aviation Authority (Ibid). The decision allowed orange County to charge a real estate tax on a shopping center that leased its land from a city owned airport. Florida is now deciding whether the ruling applies only to land owned and leased by cities and quasi-governmental agencies, or to all state owned leased property. Legal action on the new taxes is pending in Florida, and Rhode Island should monitor it for future guidance.

\section{INSURANCE LIABILITY ON SUBMERGED LANDS}

Insurance costs can be significant for facilities like marinas that are open to the public. In a survey of Florida marinas, $54 \%$ of marinas contacted listed rising insurance costs as the number one obstacle limiting their expansion (Bell 1990). Although most marinas carry insurance covering liability, Rhode Island should address the issue when it drafts a marina leasing program. When the state implements its plan, marinas may question if they are the responsible party for carrying insurance on the submerged lands. Marinas may claim that Rhode Island is now part or solely 
responsible for carrying insurance, since it has undertaken the role of a landlord, by receiving rents on their submerged lands. Furthermore, if marinas are required to provide public access under a marina leasing plan, they will not want to incur the associated liability costs.

To address these concerns Rhode Island should adopt a policy on liability in its marina leasing program. The present Rhode Island Marina Certification Program addresses the issue of liability by transferring responsibility to marinas as a condition of becoming certified. To become certified marinas must agree to the following provision:

licensee shall be fully and completely liable to state, and shall waive any claims against state for compensation or otherwise, and shall indemnify, defend, and save harmless state and its agencies, employees, officers, directors, and agents with respect to any and all liability (RI Marina Certification 1993)

When Rhode Island drafts its marina leasing plan a similar provision should be inserted as a condition of the lease. with the majority of marinas already carrying insurance on their facilities, such a requirement should not increase operational costs for marinas.

If public access becomes a condition of Rhode Island's leasing program, marinas may see a rise in insurance costs. To address liability, Rhode Island must decide what degree of risk the marinas will be liable for as lease holders. As a policy decision, Rhode Island may find that marinas should 
sustain the increased liability burden of public access, including public boat ramps, fishing sites, etc. Another approach would be to pass a general law that provides limited protection against liability claims for all marinas that allow public access. Maine has taken such an approach with private landowners by passing a law called "Limited Liability for Recreational or Harvesting Activities". The law provides that:

An owner, lessee or occupant of premises shall owe no duty of care to keep the premises safe for entry or use by others for recreational or harvesting activities or to give warning of any hazardous conditions, use, structure or activity on these premises to persons entering for those purposes (14 M.R.S.A. 159-A(2)).

The law allows that a landowner does not have an affirmative duty of care to protect a person who enters his or her land for recreational or harvesting purposes from injury, due to the condition of the premises or any hazardous condition, use, structure, or activity on the premise. The law defines landowners as owners, lessees (individuals who lease an interest in the premises), and occupants of the premises. The standard is the same, no duty of care, regardless of whether the person enters with or without permission of the owner. In Maine, the law applies to improved and unimproved lands, private ways, any buildings or structures on those lands and waters standing on, flowing through, or adjacent to those lands (Ibid). This law could provide further 
protection to marinas by extending liability coverage to uplands crossed over to gain access to adjacent submerged lands. The law does have exceptions where the landowner would be liable. In situations where the landowner willfully or maliciously fails to guard or warn against a dangerous condition, use, structure or activity, the liability law would not apply. Also, the law would not apply when the landowner receives compensation in exchange for granting permission to use the land for recreational or harvesting activities (Ibid). The Maine courts have restrictively interpreted the exceptions to the statute, and have recognized it as an important policy tool to facilitate public recreational access.

In Rhode Island a similar version of Maine's law was passed, but it requires active participation from a landowner for it to apply. Called the "Landowner Liability Law", it was enacted by the Rhode Island General Assembly in 1977 (Johnson 1988). To qualify for coverage a landowner must register with the Rhode Island Department of Environmental Management (DEM). When registering the landowner gives voluntary permission to open up such lands to the general public without charge for recreational purposes. In its current form the law could be used for marinas that are required to provide public access under a marina leasing plan. To provide protection, marina owners 
would need to register proposed public access sites with the state. Although this law has been in existence since 1977, it has largely been ignored in Rhode Island. A more practical approach may be to amend this law to provide the comprehensive blanket coverage characteristic of Maine's version. This would automatically provide marinas with limited liability protection without requiring marina owners to register their lands with the state.

If a law such as Maine's was adopted by the Rhode Island General Assembly, or the Rhode Island version was amended, it would help resolve problems associated with liability on submerged lands. For the marinas who lease submerged lands and provide public access, it may reduce their insurance premiums. Marinas may also be more receptive to public access requirements, if their liability burden was reduced by a general law. 
CHAPTER 6 CONCLUSIONS AND RECOMMENDATIONS

From a review of legal decisions and the Rhode Island Constitution, it is clear that the state maintains the authority to lease marinas their submerged lands under the power of the Public Trust Doctrine. Whether Rhode Island adopts a marina leasing program remains more of a public policy question. With the adoption of a marina leasing program, the state will better serve the public as Trustee over its submerged lands. Marinas will also benefit from a leasing program, as pending questions involving titles and bank loans on their facilities will be resolved. A leasing program would further allow marinas to improve their operations by providing stability for long term planning. A review of other coastal states programs, has demonstrated that submerged land leasing programs are now a popular coastal management tool. All of the west coast states have implemented marina leasing programs, and most of the southern and eastern coastal states have adopted a plan, or are presently considering the adoption of one. Based on the review of other marina leasing programs, and the hypotheses explored here, the following recommendations are made.

As a public policy position this thesis recommends that Rhode Island should progress forward with a marina leasing program. Before Rhode Island again tries to implement a leasing program, the CRMC needs to develop a strategic 
implementation plan. A comprehensive marina leasing program which addresses problems, including those brought up at previously held public hearings should be developed prior to going public. After such a plan is developed another series of public hearings should be held. This would provide for greater public input, and allow the CRMC to defend concerns associated with the previously proposed program. If CRMC takes these steps, the chance that organized opposition from marine associations and the public will again halt a plan, will be reduced.

One of the most important features in any marina leasing plan is the lease fee formula. Rhode Island's current proposed formula is not only inequitable to marinas, but also would not generate enough funds to justify the bureaucracy associated with setting up the program. Based on a 1988 survey done by the International Marina Institute, it was estimated that Rhode Island marinas contain somewhere around 10,000 slips (Ross 1988). At Rhode Island's current proposed rate of $\$ 10.00$ per slip, the total amount of revenue generated from a marina leasing program would be on the order of $\$ 100,000$. This figure can not be expected to cover the implementation and operation costs associated with establishing such a program. By adopting of one of the previously discussed leasing formulas, Rhode Island could generate enough income to warrant the creation of a marina 
leasing program. In its current form, it seems probable that implementation of the plan will result in the creation of yet another state regulatory agency from which no operational budget is available. In a time of growing public awareness about government bureaucracy, implementation of such a plan would be a costly political and public policy mistake.

To provide marinas with the most equitable formula currently available, and generate enough income to justify a program, it is recommended that CRMC use Maine and Michigan's percentage of slip revenue lease formula. The adoption of this formula will reduce complaints among marinas in regarding inequitable rates. To reduce the initial financial burden on marinas, Rhode Island should opt for a lower rate, perhaps $2 \%$ or $1 \%$. As Table 5 demonstrated, even at the lowest rate of $1 \%$, the program would still bring in almost $300 \%$ more revenue than Rhode Island's proposed plan. The adoption of a rate lower than $4 \%$ may also make the initial implementation of marina leases more acceptable to the industry. In order to allow the State flexibility to adjust the rate, the lease should include appropriate language which considers a rate adjustment every 5 years based on the consumer price index. The current CRMC practice that grants license terms of 50 years should be eliminated, and replaced with a 30 year 
lease. This shorter term lease will give Rhode Island greater control over its submerged lands, by allowing the State to negotiate renewals more frequently. Marinas should be given an automatic renewal option, but Rhode Island may want to retain the right to negotiate new lease conditions if required. To address large marina projects, Rhode Island should maintain a provision that allows for a maximum lease term of 50 years. This policy would permit marinas to negotiate a longer term lease, in situations where financing may be problematic. Marinas applying for longer term leases, should pay additional fees as is required in Florida's leasing program.

The leases should also include specific provisions to address both taxes and liability. To resolve tax problems the marina leases should include a provision finding the marinas as the responsible party for fees associated with the property, including both state and municipal taxes. Most States have such language in their leases, and Rhode Island should simply adopt a provision from another state's plan. By including such language in the lease, Rhode Island will eliminate concerns from cities and towns on the potential implications to their tax bases. The State could also adopt a section of previously proposed legislation on filled tidal lands, which addressed taxes. The legislation was introduced to the Rhode Island General Assembly in 1992, 
after the Hall decision, and it contained language directly addressing taxes. This legislation would grant municipalities the authority to tax filled lands as agents of the state, and keep all revenues from such taxes (Boyle 1992). If such legislation was adopted then a tax policy which clearly stipulates who is responsible for the payment and collection of taxes on marinas' submerged lands would be established.

The lease should also contain a clause that declares marinas are liable for all damages and claims, occurring on their submerged lands, and thus release Rhode Island from liability responsibilities. The clause can be duplicated from the version in the current marina certification program, or another state's program, as most have some type of language to address liability. Perhaps Michigan's program could be used as a guideline, since its program has been instituted for the longest time.

Another public policy issue that Rhode Island must address, is whether to grant pre-existing marinas an exemption from a lease and, if so, for how long. The implementation of such an exemption will require the selection of a control reference date. Both Maine and Florida have offered an exemption for marinas in existence prior to a certain date. For Rhode Island, tentative 
control dates, could be the creation of CRMC in 1971, or the date in which the proposed leasing program goes into affect. If an exemption was offered, the time period of the exemption would need to be established. While an exemption in Rhode Island may make implementation more acceptable to marinas, it is however recommended that the state does not offer a lease exemption, or a grandfather clause. With the majority of Rhode Island's marinas in existence prior to the creation of the CRMC, an exemption applying that date would include almost every marina in the state. Only the few marinas built after the CRMC was established would require a lease, and that would submit them to an economic disadvantage. The use of a later date, such as the beginning of the lease program itself, would grandfather in all existing marinas and eliminate all revenue potential. Given that Rhode Island's shorefront has very few sites left where marinas may be developed; the chance of new marinas being built is limited. This implies that Rhode Island would be responsible for the budget to maintain the program, until the exemptions expire. For these reasons it is recommended that all marinas in Rhode Island be brought under a lease within one year of the establishment of a marina leasing program.

Public access should become the priority in Rhode Island's marina leasing program. In order to encourage 
public access, the program should include fee reductions, similar to Florida's $30 \%$ fee reduction, for marinas open to the public on a first come first basis. To promote further public access the lease program should offer additional fee reductions for marinas offering services such as boat ramps, and public fishing piers. As the conditions of each marina's facilities will limit the type and magnitude of public access, Rhode Island should maintain the right to negotiate separate fee reductions with each lease, as is currently done in California. During the lease renewal, Rhode Island must encourage public access as a primary goal. The fees generated from a marina leasing program should be used to provide for greater public access. A special fund should be established that allows revenues from the leases to be used only for the programs operational costs, with any additional revenues placed in a restricted fund. This fund should provide for improvements in existing public access ways, or the establishment of new ones. Helping to establish and maintain sites like the state fishing pier proposed for the old Jamestown bridge would be a perfect example of how to spend these funds.

Rhode Island's marina certification program, established in 1993, sets a good foundation on which the State can establish marina leasing program. First, all marinas which register under this program must sign a form 
which clearly identifies Rhode Island as title holder to the marina's submerged lands. The certification forms further state that submerged lands are subject to Public Trust principles. Through this acknowledgement, the CRMC has established the necessary precedent for a marina leasing program. To facilitate the implementation of a leasing program, the CRMC should continue to register Rhode Island marinas under the marina certification program, extending the program if necessary.

One of the requirements of the marina certification program is that marinas establish a square foot area for their facility. All marinas must set a perimeter to define that portion of tidal waters in which the marina intends to conduct its operations, and be approved by a Rhode Island registered land surveyor. With square foot area already calculated on the marinas, Rhode Island would simply need to set a square foot rate in order to implement a marina leasing formula.

The Rhode Island marina certification program would need only one additional requirement to enact the linear foot method. To be certified a marina must show a diagram of in water facilities (i.e. piers, ramps, piles, etc.), and establish the boating capacity for its existing slip layout. To enact the linear foot program Rhode Island could further require marinas to additionally include the total amount of 
linear feet their docks add up to for their certification. If Rhode Island adopted such a system, it should establish a rate formula like Texas' where total dock length, not boat length, is used to determine total linear feet. This significant caveat is necessary because the actual amount of linear feet a marina leases can depend on how its slips are leased, and can fluctuate from year to year. The actual amount of slip footage leased varies because it is common practice for marinas to rent a 30 foot dock to a 25 or 40 foot boat. In such a case, the slip fee is based on the greater of the two lengths.

In addition, many marinas reserve a certain number of slips as transit slips, which are rented to boats according to their length, on a daily basis. Fees collected from transit slips vary depending on the actual length of the boat docked that day. Therefore, a leasing system based on linear feet of actual dock footage would be less problematic to implement than one based on actual boat lengths.

In conclusion, this review shows that Rhode Island has the legal and political framework to implement a marina leasing program. However this analysis also reveals inconsistencies and weaknesses in the current proposed plan. While it is advised that this plan not be implemented in its present form, it is recommended that the state amend the plan for future use. Through restructuring of the fee 
system, and the addition of carefully worded specifications to address problems associated with leasing, Rhode Island could effectively have a plan ready for implementation by the end of 1994. With no doubt, both the citizens and the marinas of Rhode Island better served by the adoption of a fair and effective marina leasing program. 


\section{BIBLIOGRAPHY}

Bell, Fredrick. Economic Impact of Bluebelting Incentives in the Marina Industry in Florida. Gainesville, FL: Florida Sea Grant Program, Prog. No. R/MI-8, 1989

Boyle, Christopher. "An Act Relating to Filled Tidal Lands. Draft Legislation. State of Rhode Island General Assembly". January, 1992 .

California General Laws. Article 2-2004(b), California Land Board, State Property operations, 1990.

California Submerged Land Lease. California state Lands Commission, 1992 .

California State Lands Commission. A Report, 1990.

Cassell, Harold. The Public Trust Doctrine and Submerged Lands Management: Comments on a Challenge in Maryland, Maryland Board of Public Works, 1989.

Collins, C., and S. Sedgwick. Recreational Boating in Rhode Island's Coastal Waters: A Look Forward. Marine Tech. Rpt. 75, University of Rhode Island, Kingston Rhode Island. 1979.

Comerford, Robert. Marina and Boatyard Industry Financial Performance, International Marina Institute, Wickford, Rhode Island. 1987.

East Passage Yachting Center Marina Brochure. Portsmouth Rhode Island, 1994.

Flannery, Jim. "Florida Counties Consider Taxing of Submerged Land." Soundings Trade Only, April 1993, pp.10

Flannery, Jim. Florida Extends Amnesty Offer for Lease of Submerged Lands, Soundings Trade Only, December, 1990.

Florida Administrative Code. General Laws. Sovereignty Submerged Lands Management Chap. 18-21, 1982.

Florida Submerged Lands Plan. Dept. of Natural Resources, State of Florida, 1992.

Goat Island Marina Brochure. Newport, Rhode Island. 1993. Gifis, Steven. Law Dictionary, 2nd Edition. New York, Barrons Educational Series, 1984. 
Hedrick, Jerry. A Letter Responding to the Submerged Lands Program, Oregon Waterway Lease Administrator. Oregon, 1992.

Jarman, Casey. and Richard McLaughlin, "A Higher Purpose? The Constitutionality of Mississippi's Public Trust Tidelands Legislation". Mississippi Law Review, Vol.11 1990 .

Johnson, George. "Designing a Coastal Public Access Program for the Ocean State: A Post- Nolan Assessment". Rhode Island Division of Planning. Tech. Paper No. 132, 1988.

Kalo, Joseph. Coastal and Ocean Law. Marshall Publishing Company: Texas, 1990

Lyon, Gale. Economic Analysis of Marinas in Maryland. Unv. of Maryland. Phd. Dissertation 1967.

Maine General Laws. 12 M.R.S.A. 558, 1975.

Maine General Laws. 12 M.R.S.A. 558-A, 1991.

Maine's Submerged Lands Rules. Bureau of Public Lands, 1992 .

Maryland General Laws. Title $9 \mathrm{Sec}$ 101-204. Wetland and Riparian Rights, 1990.

Maryland Department of Natural Resources Water Resource Administration. Bill Report on Tidal Wetlands Annual Lease Payments, 1992 .

Massachusetts. "Coastal Zone Management Report on Submerged Lands". 1987.

McKann, Michael. Model Marina for Texas, Marina Association of Texas, May 1987.

Michigan's Great lakes Submerged Lands Act. Public Act 247 as Amended, Section 322.701-322.1018, Michigan General Laws, 1955.

Michigan Submerged Land Lease. Michigan Submerged Lands Management Unit, Land and Water management Division, Dept. of Natural Resources, 1992.

Miller, Mark. Synopsis of the Bureau of Submerged Lands and Preserves, Florida Dept. Natural Resources, 1992.

Mississippi Report of the Blue Ribbon Commission on Public Trust Tidelands. Mississippi Sec. of State, January, 1989. 
Mississippi Rules for the Administration, Control and Leasing of Public Trust Tidelands, Mississippi Sec. of State, 1991 .

Nixon, Dennis. " Evolution of Public and Private Rights to Rhode Island's Shore" . Suffolk University Law Review. Vol. 24 No. 2, 1990.

Oliveri, Steve. "Interview". Resource Administrator, Bureau of Public Lands, Maine Dept. of Conservation, September, 1992.

Olsen, Stephen., Robadue, Donald and Virginia Lee, An Interpretive Atlas of Narragansett Bay, Coastal Resource Center, University of Rhode Island. Marine Bulletin No. 40 1980 .

Oregon Administrative Rules 141-82-005-035. Oregon Division of State Lands, 1992.

Oregon Division of state Lands. Statement of the state Land Board: Leasing Program of State of Oregon, 1981.

Pompe, Jeffery. Marina Characteristics and Wet Slip Pricing: An Application to Policy, Coastal Management, Vol. 20 , pp. 355-363. 1992 .

Protection Against Liability for Landowners Who Allow Public Access. Unv. Maine, Marine Law Institute. Orono, Maine. 1990 .

Public Submerged Lands lease Fees Revised. Unv. Maine, Marine Law Institute. Orono, Maine. 1991

Rhode Island Coastal Zone Management Plan. 1978.

Rhode Island Coastal Zone Management Plan. 1983

Rhode Island Marina Certification Program. Rhode Island Coastal Resource Management Council, (1993).

Rhode Island General Laws. 46-23-1 (1979)

Rogers, Golden and Halpern,. Developing a Marina in New Jersey: A Handbook, New Jersey Dept. Environmental Protection, Division of Coastal Resources. 1982.

Ross, Neil. Rhode Island Recreational Boating Facilities. International Marina Institute, Wickford, Rhode Island. 1988. 
Rubin, Michael. Brief of Amicus Curiae Hall V Nascimento, 594, A.2d, 874, RI 1991 C. A. No. 89-0612 1991 .

Slade, David. Putting the Public Trust Doctrine to Work. Connecticut: Coastal States Organization, 1990.

Tannenbaum, Mitchell. "The Public Trust Doctrine in Maine's Submerged Lands: Public Rights, state obligation and the Role of the Court"s: Maine Law Review, Vol. 37 No. 1, 1985

Texas Land Commission. General Laws on Management of Public Land, Texas, Natural Resource Code, 33.063. 1991.

The Narragansett Times. February 21, 1992

U.S. Department of Commerce. United States Census, 1990 .

Zarafonitis, Bess. Underwater Lease Fees Modified for Marina Owners in Maine, Soundings Trade Only, October, 1992 . 